\title{
Review
}

Pharmacology

\section{The Non-Neuronal Cholinergic System in Health and Disease}

\author{
Janet Beckmann Katrin Susanne Lips \\ Laboratory for Experimental Trauma Surgery, Justus Liebig University, Giessen, Germany
}

\section{Key Words}

Non-neuronal cholinergic system · Acetylcholine · Nicotinic receptors · Muscarinic receptors · Choline

acetyltransferase - Vesicular acetylcholine transporter .

Organic cation transporter - Acetylcholinesterase

\begin{abstract}
Acetylcholine (ACh) is not only a neurotransmitter but is an ancient molecule that can be released by and act on nonneuronal cells. In these cells the system of ACh-synthesizing enzymes, transporters, receptors and degrading enzymes is termed the non-neuronal cholinergic system (NNCS). There is increasing evidence that the NNCS is dysregulated in various diseases and can have an influence on their pathology. However, for many organ systems not much is known about the expression and function of the NNCS. Thus, this review focusses on the role of the NNCS in different organ systems in health and disease. Dysregulation of ACh synthesis and release, mutations or polymorphisms in genes encoding NNCS components, and auto-antibodies against NNCS components are common factors influencing disease progression. Pharmacological agents targeting the NNCS are already successfully in clinical use for some disorders, indicating that interfering with this system is very promising and more research is needed to elucidate the role of the NNCS in different tissues and pathological states.
\end{abstract}

(C) 2013 S. Karger AG, Basel

\section{Introduction}

The term cholinergic system is commonly used for the well-known neurotransmitter acetylcholine (ACh) and the system of synthesizing enzymes, transporters, receptors and enzymes for degradation. ACh was the first neurotransmitter that has been identified in 1926 by Otto Loewi; for that he and Sir Henry Dale received the Nobel prize in 1936. In the following years most effort was put into exploring the neuronal cholinergic system where ACh was identified as neurotransmitter of the postganglionic parasympathetic system, the preganglionic neurons of the sympathetic system, in sweat glands of the human axilla, and in several areas of the brain. However, in view of phylogenesis, the non-neuronal cholinergic system (NNCS) already existed in non-neuronal cells like bacteria, algae and protozoa before the nervous system was developed (reviewed in Wessler et al. [1]). After rediscovery of the NNCS in the 1990s, the research was focussed on the distribution, the functions, the molecular components and its involvement in pathological conditions. One of the best-reputed organs in this regard is the skin. But besides the skin, the NNCS was found in many organ systems and for some a role in disorders has already been described. Cholinergic receptors seem to be expressed by nearly all cell types; however, the expression of the receptors alone is not an indication of the NNCS, but it is characterized by its ability to synthesize and re-

\section{KARGER}

E-Mail karger@karger.com

www.karger.com/pha
(C) 2013 S. Karger AG, Basel

0031-7012/13/0926-0286\$38.00/0
Katrin Susanne Lips

Laboratory for Experimental Trauma Surgery Justus Liebig University Giessen

Kerkrader Strasse 9, DE-35394 Giessen (Germany)

E-Mail Katrin.S.Lips@ chiru.med.uni-giessen.de 
lease ACh. Cells that exhibit solely cholinergic receptors can serve as effector cells for non-neuronally as well as neuronally synthesized and released ACh. Thus, the presence of an NNCS has to be classified before considering its involvement in organ-specific disorders. The same molecular components that are necessary for synthesis and release of $\mathrm{ACh}$ in neurons are often identified in non-neuronal cells as well. In neurons and most nonneuronal cells, ACh is synthesized by the enzyme choline acetyltransferase (ChAT) from choline and acetyl coenzyme A $[1,2]$. It was shown that ACh can also be produced by the enzyme carnitine acetyltransferase (CarAT) in some non-neuronal cells, e.g. skeletal muscle cells and the urothelium $[3,4]$. The rate-limiting step in ACh synthesis is the re-uptake of the essential nutrient choline. In the nervous system this is mediated by the high-affinity choline transporter-1 (CHT1) [5]. In some non-neuronal cells CHT1 is also present [6-8], whereas in others the re-uptake of choline is performed by choline transporter-like proteins (CTL1-5) $[9,10]$ or organic cation transporters (OCTs). In neurons ACh is stored and released by the vesicular acetylcholine transporter (VAChT) [11], whereas in non-neuronal cells VAChT is only expressed cell type specifically [12]. In cells that do not express VAChT, ACh is usually not stored but directly released via OCTs $[13,14]$. Further, the mediatophore [15], a protein of $220 \mathrm{kDa}$ consisting of $15-\mathrm{kDa}$ proteolipid subunits of the vacuolar $\mathrm{H}^{+}$-ATPase, is also discussed to be responsible for ACh exocytosis [15]. Extracellular ACh exerts its effect on a variety of different nicotinic and muscarinic ACh receptors. Nicotinic ACh receptors (nAChRs) are ligand-gated cation channels consisting of 5 subunits. Nine $\alpha$-subunits and $4 \beta$-subunits are known. The subunits $\alpha_{2}-\alpha_{7}$ are combined in heteropentamers with $\beta$-subunits, whereas $\alpha_{9}$ and $\alpha_{10}$ can form $\alpha$-heteropentamers and $\alpha_{7}$ and $\alpha_{9}$ can assemble to homopentamers [16]. Interestingly, some nAChR compositions, e.g. the homopentameric $\alpha_{7}-\mathrm{nAChR}$, were shown not only to have ion channel functions but to serve as metabotropic receptor $[17,18]$. Recently, members of the lymphocyte antigen-6/urokinase-type plasminogen activator receptor superfamily were identified as endogenous allosteric modulators of $\mathrm{nAChR}$, with SLURP (secreted lymphocyte antigen-6/urokinase-type plasminogen activator receptor-related peptide)-1 and -2 being one of the most characterized members [19].

Muscarinic ACh receptors (mAChRs) are G-proteincoupled receptors subdivided into inhibitory receptors (M2 and M4) and excitatory receptors (M1, M3 and M5). $\mathrm{M} 2$ and M4 mAChR couple preferentially to $\mathrm{G}_{\mathrm{i} / 9}$ affecting

Non-Neuronal Cholinergic System in Health and Disease the adenylyl cyclase activity and inhibiting non-selective cation channels, transient receptor potential channels and potassium channels $[20,21]$. M1, M3 and M5 $\mathrm{mAChR}$ couple to $\mathrm{G}_{\mathrm{q} / 11}$ and increase intracellular calcium via generation of inositol 1,4,5-trisphosphate and 1,2-diacylglyerol $[20,21]$. The degradation of ACh into choline and acetate is catalyzed by the enzymes acetylcholinesterase (AChE) and the less specific butyrylcholinesterase.

A schematic drawing of the NNCS with the ACh synthesizing, releasing, and degrading machinery as well as $\mathrm{ACh}$ receptors and their modulators is depicted in figure 1.

Modulation of the neuronal cholinergic system, e.g. by AChE inhibitors, is a common treatment for neuronal diseases like e.g. Alzheimer's disease. For some diseases targeting the NNCS with cholinergic drugs is a well established treatment. However, in many non-neuronal tissues not much is known about the expression and function of the NNCS. The aim of this review is to give a short overview on the involvement of the NNCS in several pathological conditions and on the occurrence of the NNCS in healthy tissue and its basic functions there.

\section{Integumentary System}

The integument is composed of the skin and its derivates, e.g. glands, hair and nails. The most significant cell types of the skin are keratinocytes that are able to synthesize ACh in high amounts. A single keratinocyte synthesizes and releases a mean of $2 \times 10^{-17} \mathrm{~mol} \mathrm{ACh}$ and $7 \times$ $10^{-19}$ mol ACh per minute, respectively [22]. Keratinocytes also express members of both classes of ACh receptors, the necessary transporters for an efficient auto-/ paracrine cholinergic loop, and the degradation enzyme AChE. Skin fibroblasts and melanocytes exhibit molecular components of the NNCS; however, most information about the NNCS is available from keratinocytes. The skin NNCS is assumed to regulate the intimate connection of keratinocytes, proliferation, differentiation, apoptosis, adhesion and migration [23]. Thus, in healthy skin the NNCS is of great impact. Under pathological conditions it is involved in several diseases.

Atopic dermatitis is a chronic, inflammatory, pruritic skin disorder in which ACh levels are elevated 14-fold in the superficial epidermis and upper dermis and 3-fold in the underlying dermis and hypodermis [23, 24]. Allergens, infections, environmental pollutants and emotional stress trigger the clinical onset of disease with main fea- 
Fig. 1. Schematic drawing summarizing the components of the NNCS involved in the synthesis, release, degradation and signalling of non-neuronal ACh. BChE = Butyrylcholinesterase.

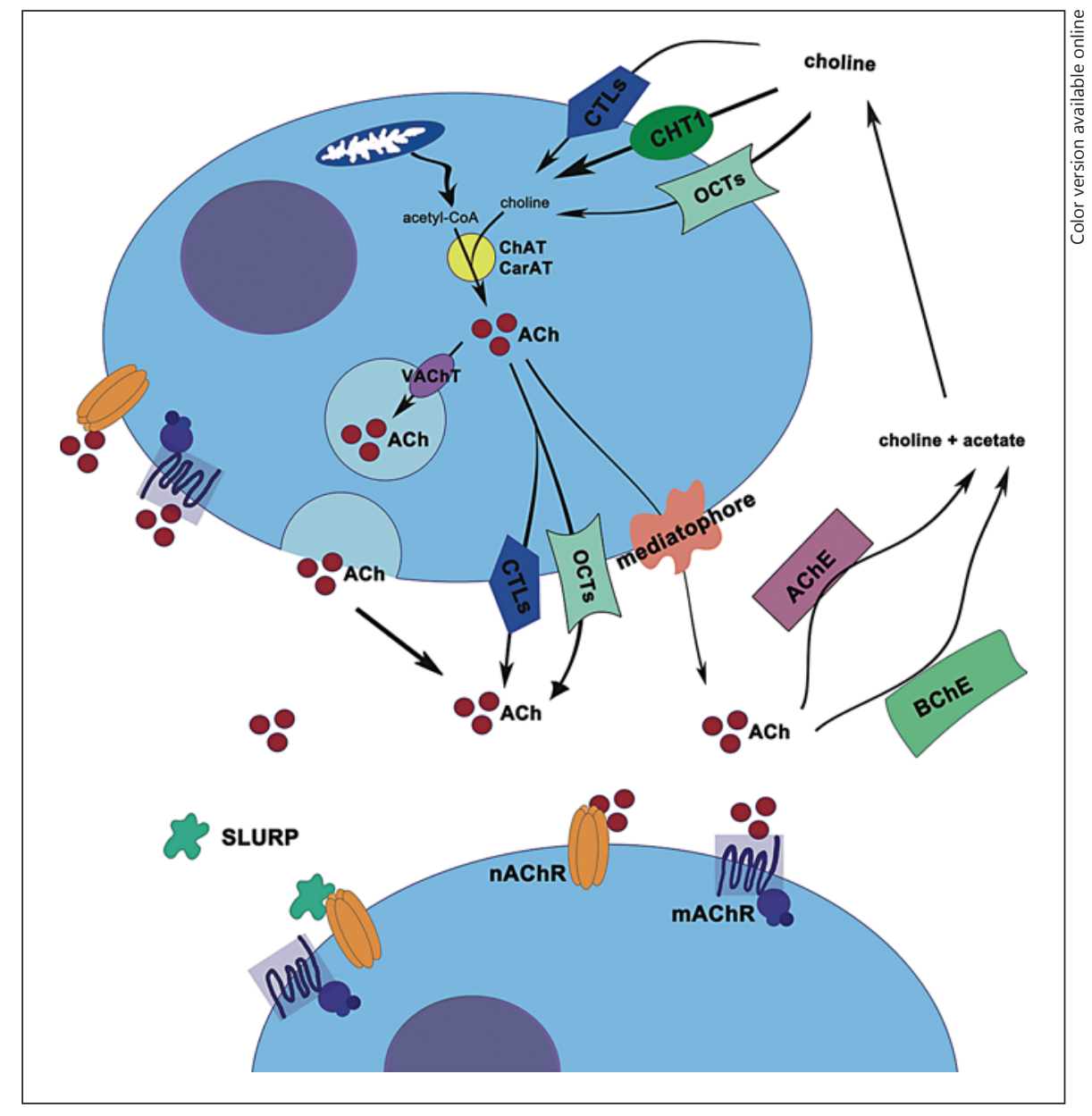

tures being eczematous skin lesions [25]. In a mouse model the histopathology of atopic dermatitis could be completely prevented by pretreatment with corticotropin-releasing hormone which is released in response to cholinergic stimulation [26]. These results indicate that $\mathrm{ACh}$ and the cholinergic system are involved in the regulation of atopic dermatitis [27].

Vitiligo is a chronic, non-infectious disease that is characterized by patchy loss of skin pigmentation, most prominent on the face, hands and wrists. The affected melanocytes contain a high amount of $\mathrm{H}_{2} \mathrm{O}_{2}$. AChE is regulated by $\mathrm{H}_{2} \mathrm{O}_{2}$. High concentrations of $\mathrm{H}_{2} \mathrm{O}_{2}\left(10^{-3}\right.$ $\mathrm{mol} / \mathrm{l})$ inhibit $\mathrm{AChE}$, whereas low concentrations of $\mathrm{H}_{2} \mathrm{O}_{2}$ $\left(10^{-6} \mathrm{~mol} / \mathrm{l}\right)$ activate the enzyme by increasing the maximum reaction velocity by $>2$-fold [28]. AChE is deactivated by $\mathrm{H}_{2} \mathrm{O}_{2}$-mediated oxidation of the amino acid residues $\operatorname{Trp}(432), \operatorname{Trp}(435)$ and Met(436), leading to an alteration of the active site His(440) and subsequently to the inhibition of the enzyme [28]. This mechanism should be taken into account for the regulation of the skin NNCS because $\mathrm{H}_{2} \mathrm{O}_{2}$ can be generated in the millimolar range via UV radiation [23].

Mal de Meleda is a rare autosomal skin disorder that is characterized by a palmoplantar keratoderma. An underlying mutation in the ARS B gene (EMBL AC: X99977) leads to a lack in the non-canonical $\alpha_{7}$-nAChR ligand SLURP-1 [19], which enhances the amplitude of the ACh-evoked macroscopic current [29]. These data suggest that SLURP-1 and the non-neuronal cholinergic pathway provide the fine-tuning of keratinocyte functions [23].

Psoriasis is an immune-mediated non-contagious skin disorder with typical generation of plaques. The nAChR modulator SLURP-2 is 3.8- and 2.8-fold upregulated in psoriatic lesional skin in comparison to normal skin and psoriatic non-lesional skin, respectively [30]. SLURP-2 binds predominantly to the ligand binding sites of $\mathrm{AChR}$ subunits $\alpha_{3}$ of keratinocytes, thus being involved in the 
pathophysiology of psoriasis through regulation of differentiation and apoptosis [31].

Pemphigus is a rare auto-immune disease with typical creation of blisters caused by auto-antibodies against about 50 antigens, e.g. desmogleins and $\mathrm{ACh}$ receptors (M1, M2, M4, M5 mAChR and nAChR subunits $\alpha_{3}, \alpha_{9}$ and $\alpha_{10}$ ) [32]. Because of this diversity of auto-antibodies, several hypotheses about the causes of pemphigus were formulated. Grando et al. [23] proposed a multiple-hit hypothesis with an interplay of antigens regulating cell shape and cell-to-cell adhesion. However, non-neuronal auto-/paracrine ACh seems to be involved in the pathology of pemphigus. Administration of the angiotensinconverting enzyme inhibitor captopril increased the AChE concentration significantly, leading subsequently to a reduction of $\mathrm{ACh}$ and might therefore induce generation of the typical pemphigus blisters by acantholysis [33].

Palmoplantar pustulosis occurs mostly in smokers where blisters appear on the palms and soles. Abnormalities in the expression of ChAT, AChE and nAChR subunits $\alpha_{7}$ and $\alpha_{3}$ were determined [34] and hence concluded that smoking and the NNCS are involved in this cutaneous inflammatory disease $[23,35]$.

The majority of epidemiological studies demonstrated an association of smoking and the incidence of certain types of skin cancer. Smoking is a risk factor for cutaneous squamous cell carcinoma [36] whereas it lowers the risk of classic Kaposi's sarcoma [37]. However, tobacco-derived nitrosamines stimulate the $\alpha_{7}$-nAChR expressed by oral keratinocytes and subsequently lead to activation of STAT (signal transducer and activator of transcription)-3 and STAT-2 via the Ras/Raf-1/MEK1/ERK pathway and Janus kinase (JAK)-2 pathway, respectively [38]. Thus, the $\alpha_{7}-\mathrm{nAChR}$ is a promising molecular target for therapeutic intervention.

Multiple cells and processes are involved in cutaneous wound healing. One step with distinct participation of keratinocytes is the epithelialization. Chernyavsky et al. [39] demonstrated that SLURP-1 slows keratinocyte migration but enhances anti-inflammatory activity whereas SLURP-2 increases the outgrowth of keratinocytes dosedependently and has a lesser anti-inflammatory effect than SLURP-1. Thus, distinct nAChR are able to stimulate wound repair via regulation of keratinocyte migration and inflammation.

\section{Respiratory System}

The respiratory system consists of different organs (e.g. nose, nasopharynx, trachea and lung) that are involved in the transport and exchange of the respiratory gases oxygen and $\mathrm{CO}_{2}$. The luminal surface of the airways is covered by the respiratory epithelium consisting of at least 12 cell types. Airway fibroblasts and inflammatory cells are also involved in airway pathophysiology. Moreover, autonomic nerve fibres occur close to airways, bronchial and tracheal smooth muscle and submucosal glands. Thus, it can hardly be discriminated between effects caused by the neuronal or the non-neuronal cholinergic system. However, it is well known that neuronally released ACh triggers mucus secretion and bronchoconstriction via muscarinic receptors that limit airflow [40]. nAChR were also determined in the airways, e.g. on fibroblasts, immune cells and epithelial cells [41]. Stimulation of the cholinergic receptors on epithelial cells leads to enhanced proliferation $[42,43]$ and improved cell survival [43]. Cleaning the airway surface from inhaled particles is facilitated by mucociliary transport which is driven by ciliary epithelial cells. ACh is known to regulate the ciliary beat frequency via different $\mathrm{mAChR}$. While activation of M3 mAChR stimulates ciliary-driven particle transport, signalling through $\mathrm{M} 2 \mathrm{mAChR}$ inhibits this process [44].

ACh itself has also been determined in rat tracheal epithelium $(2.8 \pm 0.5 \mathrm{nmol} / \mathrm{g})$ as well as in human bronchial epithelium (23 $\pm 6 \mathrm{pmol} / \mathrm{g})$ [45]. Moreover, additional evidence was provided for the synthesizing enzyme ChAT and acetylcholine transporters like OCT, CHT1 and VAChT (reviewed in Kummer et al. [12]). But some of these molecular components were restricted to one or only few cell types of the respiratory epithelium. Thus, the respiratory NNCS is considered to be cell type specific, a fact that complicates the attribution to pathological conditions.

\section{Asthma and Chronic Obstructive Pulmonary Disease}

Peribronchiolar fibrosis is observed in small airways of patients with asthma and chronic obstructive pulmonary disease (COPD). A key step of the formation of peribronchiolar fibrosis is the transition of fibroblasts into secretory active myofibroblasts that are identified by the increased expression of $\alpha$-smooth muscle actin and collagen type-1 [46]. This takes place under chronic inflammatory conditions. Recently it has been shown that the remodelling into myofibroblasts could be reversed by administration of the anticholinergic aclidinium bromide, by silencing M1, M2 or M3 mAChR mRNA or by 
degradation of ACh using AChE treatment [47]. Thus, the NNCS is involved in one of the key steps of COPD and asthma consolidation. Furthermore, the NNCS was shown to be downregulated in an acute allergic airway inflammation animal model [48]. The immunomodulatory effects of ACh in asthma and COPD have been reviewed in detail by Gwilt et al. [49]. In brief, ACh is assumed to inhibit the early asthmatic reaction by preventing mast cell degranulation but stimulates the lymphocyte-driven inflammation by enhancing lymphocyte survival and proliferation. In COPD, ACh stimulates the inflammatory actions of epithelial cells and lymphocytes leading to an increase in pro-inflammatory cytokines. In general, in the respiratory system, ACh seems to be proinflammatory in lymphocytes and epithelial cells, antiinflammatory in mast cells and macrophages and can exert both effects in monocytes [49].

\section{Lung Cancer}

Approximately $80-90 \%$ of all lung cancer cases are considered to be associated with cigarette smoke [50]. Nicotine was shown to induce proliferation of cancer cells and seems to even inhibit the apoptotic effect of chemotherapeutics $[18,51]$. Both small cell lung carcinoma cells as well as non-small cell lung carcinoma cells are able to synthesize and release ACh [52]. Recently, it was shown that in small cell lung carcinoma cells, ACh synthesis is positively linked to CTL4 expression [53], while the choline transport to non-small cell lung carcinoma adenocarcinoma cells can be mediated by CTL1 and CTL2 [54]. Grozio et al. [55] demonstrated that inhibition of $\alpha_{7^{-}}$ nAChR signalling with $\alpha$-cobratoxin led to enhanced apoptosis of adenocarcinoma cells in culture as well as in established tumour xenografts in vivo. Further, M3 $\mathrm{mAChR}$ seems to be a promising target for the inhibition of tumour growth, as it was shown that various antagonists for this receptor inhibited growth of lung cancer cells in vitro and in vivo [56]. Interestingly, an increased risk for lung cancer is associated with single nucleotide polymorphisms on chromosome $15 \mathrm{q} 25.1$, containing genes coding for nAChR subunits $\alpha_{3}, \alpha_{5}$ and $\beta_{4}[57,58]$ and with single nucleotide polymorphisms in the gene for nAChR subunit $\alpha_{9}$ [59]. The exact function of these single nucleotide polymorphisms and how these can be used therapeutically is still unknown and has to be elucidated in further research studies.

\section{Cystic Fibrosis}

The highly prevalent genetic lung disorder cystic fibrosis is caused by a mutation of the cystic fibrosis trans- membrane conductance regulator (CFTR) chloride channel [60]. ACh represents an important regulator of epithelial ion and water movements. In patients suffering from cystic fibrosis, the ACh content was markedly reduced [61]. Interestingly, mAChR and $\alpha_{7}-n A C h R$ seem to be regulators of CFTR $[62,63]$. Activation of $\alpha_{7}-n A C h R$ enhances CFTR-mediated chloride secretion, and CFTR and $\alpha_{7}-n A C h R$ were shown to be associated in a macromolecular complex within lipid rafts at the apical membrane of the airway epithelium [63]. Additionally, proinflammatory cytokine production in response to innate immune activation was inhibited by activation of $\alpha_{7^{-}}$ nAChR expressed on tracheal epithelial cells [64].

\section{Cardiovascular System}

Both, the neuronal cholinergic system as well as the NNCS were shown to be present in the cardiovascular system that consists of heart and blood vessels. Adult heart cardiomyocytes are able to synthesize, transport and secrete ACh [65], whereas in newborn rats ACh is only released by autonomic nerve fibres [66]. The same age-dependent expression pattern was observed for ChAT [65] that showed regional differences in its activity [67]. While in the rat ventricles only $50 \%$ of the ChAT activity observed for the atria could be detected, the highest activity of ChAT was determined in the region of the sino-atrial node [67] where ACh is responsible for reducing pacemaker activity [65]. Moreover, CHT1 [65], VAChT [65], OCT [14], nAChR [68] and mAChR [69, 70] were found in cardiomyocytes and the heart, as well as in several vascular beds [71-74] and endothelial cells [70, 75-77]. In endothelial cells ChAT and ACh itself were also detected [75]. Angiogenesis, the sprouting of new blood vessels, is indispensable for normal growth and homeostasis; however, when dysregulated it contributes to the pathogenesis of many disorders like e.g. cancer, arthritis, obesity and cardiac diseases.

Nicotine is a potent stimulator of angiogenesis, which is meditated mainly via $\alpha_{7}-\mathrm{nAChR}$ and involves mitogenactivated protein kinase and transcription factor nuclear factor- $\kappa \mathrm{B}$ activation [77]. This pathway is independent of vascular endothelial growth factor and fibroblast growth factor, the most important mediators of angiogenesis. Endothelial cells were shown to upregulate $\alpha_{7}$-nAChR under conditions associated with angiogenesis. The $\alpha_{9}-\mathrm{nAChR}$ on the other hand appears to oppose this pathway [78]. Further, application of the reversible AChE inhibitor donepezil promoted angiogenesis, indicating that it could 
be used as therapeutic tool for diseases with pathologically reduced angiogenesis like cardiac diseases [79].

Cardiac diseases like cardiac ischaemia, hypertrophy, heart failure and arrhythmias are still among the world's leading causes for death [80]. Heart functions are regulated by the autonomic nervous system interacting with the M3 mAChR which is involved in physiological and pathological conditions. Moreover, M3 mAChR promotes cardioprotection via suppression of specific miRNA in myocardial ischaemia [81]. Ischaemic heart disease is a complex disorder of great clinical impact that is often associated with well-known cardiovascular risk factors including hypertension, hyperlipidaemia, diabetes, atherosclerosis, heat failure, and aging [80].

Atherosclerosis is the major cause of heart attack, stroke and peripheral arterial disease [82] and is characterized by arterial wall thickening due to accumulation of lipids. Apolipoprotein E plays an important role in lipid metabolism, and its deficiency was shown to induce atherosclerosis in mice. In this murine model of atherosclerosis, administration of nicotine was shown to promote disease [83].

\section{Digestive System}

The digestive system consists of various organs such as the pharynx, oesophagus, stomach, small and large intestines, and glandular organs like the liver, pancreas and salivary glands.

Nguyen et al. [84] showed that in oesophageal epithelia ChAT, AChE as well as different $\mathrm{nAChR}$ subunits can be found. Reduced ACh concentrations and signalling can lead to a reduction in lower oesophageal sphincter function and subsequently to gastro-oesophageal reflux disease [85]. Additionally, a recent study on cats revealed that the NNCS could also contribute to gastro-oesophageal reflux disease by e.g. modulating cell-cell contacts, as the expression of components necessary for ACh synthesis and release, namely CHT1, ChAT, VAChT and OCT1, was altered in the oesophageal mucosa under pathological conditions [86].

The digestive tract is abundantly innervated by cholinergic neurons [87]; thus, many effects can be contributed to neuronal rather than non-neuronal ACh. Smooth muscle cell contraction of the gastro-intestinal tract is mediated by $\mathrm{M} 2$ and $\mathrm{M} 3 \mathrm{mAChR}$, the latter being less abundantly expressed, however functionally more relevant [88].

Non-Neuronal Cholinergic System in Health and Disease
Gastric pepsinogen secretion is mainly driven by $\mathrm{ACh}$ signalling via $\mathrm{M} 1$ and $\mathrm{M} 3 \mathrm{mAChR}$, as in gastric mucosa of M1/M3 mAChR double-deficient mice carbachol-induced pepsinogen secretion was abolished [89]. While M1 mAChR is only present on pepsinogen-producing chief cells, M3 mAChR can also be found on other cell types of the gastric gland [89]. Thus, M3 mAChR localized on parietal cells was reported to be mainly responsible for secretion of gastric acid [90]. Alterations in the cholinergic process of pepsinogen and gastric acid secretion can contribute to gastric and duodenal ulcers [91]. Accordingly, anticholinergic agents are successfully used as therapy for these conditions.

Cholinergic receptors play an important role in the regulation of ion transport across the intestinal epithelial cell membrane [92]. Further, enhanced M3 mAChR signalling seems to increase the permeability to macromolecules in the mouse jejunum and thus leads to barrier dysfunction which can subsequently cause initiation and exacerbation of intestinal disease [93]. It was shown that ChAT is expressed by cells of the intestinal epithelium as well as by microfold cells covering Peyer's patches [94]. Isolated rat colonic crypt cells express ChAT and OCT, and non-neuronal ACh could be measured in concentrations of 1.8 and $11.9 \mathrm{nmol} / \mathrm{g}$ for the proximal and the distal colon, respectively [95]. In the rat mucosa, the release of ACh could be further induced by stimulation with the bacterial fermentation product propionate [95].

In colon cancer cells, an upregulation of $\mathrm{M} 3 \mathrm{mAChR}$ was observed [96] and it was shown that muscarinic agonists are able to stimulate colon cancer cell migration and invasion via induction of matrix metalloproteinase-1 [97]. Further, $\alpha_{7}-\mathrm{nAChR}$ [98] and CTL1-5 [53] are present on colon cancer cells. Interestingly, knock-down of CTL4 can lead to suppression of cell growth as CTL4 expression is positively linked to ACh synthesis [53]. Like in other cancer cells, stimulation of $\alpha_{7}-\mathrm{nAChR}$ by ACh or nicotine is able to induce cell proliferation and to inhibit apoptosis of colon cancer cells [99]. $\alpha_{7}-\mathrm{nAChR}$ is negatively regulated by SLURP-1 that is also present in colon cancer cells as well as in the immune cells of the lamina propria and smooth muscle tissue of the colon $[98,100]$.

Inflammatory bowel diseases comprise disorders like ulcerative colitis as well as Crohn's disease. Patients with inflammatory bowel diseases show significantly lower AChE activity and correspondingly higher levels of miRNA-132, a post-transcriptional inhibitor of AChE [101]. Interestingly, patients with Crohn's disease or ulcerative colitis differ in their response to nicotine. While for Crohn's disease smoking clearly worsens the symp-

Pharmacology 2013;92:286-302 291 
toms [102], for ulcerative colitis it seems to have protective effects and can reduce mucosal inflammation (reviewed in de Jonge and Ulloa [103]). Patients with ulcerative colitis show an enhanced expression of M2 mAChR and a downregulation of ChAT [104] and nAChR subunit $\alpha_{3}$ [105] in the colon epithelium. The $\alpha_{7}$-nAChR plays an important role in colitis as it was shown that $\alpha_{7}-n A C h R-$ deficient mice suffered from increased severity of experimentally induced colitis [106]. However, these anti-inflammatory effects of $\alpha_{7}-\mathrm{nAChR}$ stimulation are most probably mediated by resident immune cells in the intestine expressing this receptor [107]. Further, the nAChR subunit $\alpha_{5}$ also seems to play a role in colitis as $\mathrm{nAChR}$ subunit $\alpha_{5}$-deficient mice revealed an enhanced susceptibility to experimentally induced colitis [108].

The pancreas is a gland with endocrine and exocrine function. The endocrine release of hormones is facilitated by the islands of Langerhans and the exocrine release of digestive enzymes by pancreatic acinar cells. The exocrine function was shown to be mediated by M1 and M3 $\mathrm{mAChR}$ as carbachol-induced amylase secretion was significantly reduced in $\mathrm{M} 1$ and M3 $\mathrm{mAChR}$ single-deficient mice and completely abolished in M1/M3 mAChR double-deficient mice [109]. Further, nicotine can induce the proliferation of these cells [110]. Most interestingly, pancreatic stellar cells were shown to express ChAT and $\mathrm{VAChT}$ and are able to synthesize non-neuronal $\mathrm{ACh}$, which then can induce amylase secretion in neighbouring acinar cells [111].

In the islands of Langerhans, M3 mAChR expressed on $\beta$-cells was demonstrated to be of great importance for the maintenance of blood glucose homeostasis as activation of this receptor enhances glucose-induced insulin release by $\beta$-cells and improves glucose tolerance [112]. In humans the cholinergic innervation of the islands of Langerhans is sparse; however, $a$-cells of the pancreas express ChAT as well as VAChT, thus non-neuronal ACh produced by these cells is able to enhance M3 mAChR signalling in neighbouring $\beta$-cells [113]. Transgenic mice overexpressing M3 mAChR were protected from detrimental metabolic effects like hyperglycaemia caused by a high-fat diet [112], indicating that enhanced signalling through M3 $\mathrm{mAChR}$ may be a useful treatment for type 2 diabetes.

Pancreatitis is an acute or chronic inflammation which occurs when pancreatic digestion enzymes are activated before reaching the small intestine. Its pathology appears to be aggravated by smoking [114], and pancreatic M3 $\mathrm{mAChR}$ was shown to be upregulated after induction of acute pancreatitis in the rat [115].

\section{Urinary System}

The urinary system consists of organs involved in the generation and excretion of urine and associated organic substances. Here we focussed on the urinary bladder and kidneys. Recently, proof was provided for an NNCS in the kidney comprising the synthesizing enzyme ChAT and the transporters VAChT and CHT1 [116]. ChAT was localized in the apical part of principal cells of the renal cortical collection ducts suggesting that ACh might be released into the lumen and act via an auto-/paracrine loop [116]. ACh enhances the excretion of ions and water, thereby promoting diuretic effects and hypotension [117, 118]. It is assumed that ACh acts directly on renal tubules, glomeruli and Bowman's capsule via binding to cholinergic receptors. Both, nAChR as well as mAChR were expressed in several renal regions [119-126]. Only few reports are available on the involvement of molecular components of the cholinergic system in renal pathologies. In contrast, in several bladder disorders antimuscarinic agents have been used for years as clinical first-line treatment. The autonomic nervous system regulates the urinary micturition. The parasympathetic system is responsible for the voiding, that is regulated via $\mathrm{mAChR}$ on the detrusor smooth muscle. In the healthy situation, M3 $\mathrm{mAChR}$ causes direct and $\mathrm{M} 2 \mathrm{mAChR}$ indirect contraction of detrusor muscle whereas $\mathrm{M} 1 \mathrm{mAChR}$ increases and M4 mAChR decreases the release of ACh and therefore might influence afferent nerve activity and stimulate the release of ATP and nitric oxide from umbrella cells [127]. In addition to the neuronal cholinergic system, the occurrence of a bladder NNCS has been described [4, 128, 129]. ACh could be measured in the abraded urothelium at concentrations of $0.22 \pm 0.03 \mathrm{nmol} / \mathrm{g}$ wet weight in mouse and 8 and $14 \mathrm{pmol} / \mathrm{g}$ wet weight in human samples [4]. In contrast to the nervous system and several nonneuronal organ systems, ACh was not synthesized by ChAT but CarAT and not transported by VAChT and CHT1 but by OCT [4]. The presence of ChAT and CHT1 still remains controversial $[128,129]$. However, despite this controversy, the NNCS is indisputably present in the urothelium and is accompanied by several nAChR and $\mathrm{mAChR}[130,131]$ that were also analysed in bladder disorders.

\section{Kidney and Bladder Disorders}

Acute kidney injury often caused by sepsis leads to an increased risk of death that could be significantly decreased after administration of nicotine in an animal model [132]. Thus nAChR seems to act in an anti-inflam- 
matory manner also in kidney diseases. It is still controversially discussed if the administration of nicotine improves ischaemia-reperfusion injury in the rat kidney via stimulation of $\alpha_{7}$-nAChR $[126,133,134]$. However, administration of nicotine mediates the progression of chronic kidney disease via $\alpha_{7}-\mathrm{nAChR}$ in an animal model and in human smokers where it is characterized by a progressive loss of renal function $[124,135,136]$.

The overactive bladder syndrome is clinically characterized by symptoms of urgency, nocturia and occasionally incontinence [137]. The first-line treatment is administration of antimuscarinic agents that block more or less selectively muscarinic receptors and thereby reduce the bladder tone and increase the cytometric capacity [127, 138-140]. This improvement of overactive bladder symptoms is most anticipated during the storage phase where the afferent activity is altered and an involvement of the NNCS is controversially discussed [127, 140, 141].

Bladder outlet obstruction is characterized by an intravesical outlet obstruction that is often associated with detrusor overactivity and dramatic growth responses of muscles and ganglion cells through hyperplasia and hypertrophy (reviewed in Ochodnicky et al. [142]). Recently, the NNCS was shown not to be regulated on the mRNA level in this disease [143] whereas a downregulation was measured for the neuronal nAChR subunits $\alpha_{10}$ and $\alpha_{5}$ (dorsal root ganglia L5-S2) [144]. Further, a mutation of the M3 $\mathrm{mAChR}$ is associated with the onset of bladder outlet obstruction [145]. However, the plasticity at the level of innervation leads to the assumption that the autonomic nervous system is most involved in bladder outlet obstruction, eventually in interaction with the NNCS [142].

\section{Reproductive System}

The female reproductive system comprises the vagina, cervix, uterus, oviducts and ovaries. The penis, testis and respective glands like the prostate gland belong to the male reproductive system. In females, production of nonneuronal ACh was shown for the human vagina [42], granulosa cells of the ovary [146], the placenta [147], and the oviduct [148]. Like the bladder, the uterus is richly innervated by cholinergic neurons, and contractions are mainly mediated via M2 and M3 mAChR [149]. The human placenta is not cholinergically innervated; however, non-neuronal ACh is released via OCT1 and OCT3 [147] and can regulate different physiological functions like blood flow, vascularization and nutrient transport via nAChR [150]. Further, M1-M4 mAChR are expressed

Non-Neuronal Cholinergic System in Health and Disease in the human placenta [151]. In the oviduct, different nAChR and mAChR subtypes are expressed with M3 $\mathrm{mAChR}$ being mainly responsible for an increase in calcium signalling [152], which could also play a role in myogenic contractions.

Tubal ectopic pregnancy is a complication of pregnancy where the embryo implants outside the uterine cavity, in most cases in the oviduct. Smoking increases the risk for ectopic pregnancy, a mechanism that seems to be mediated via the $\alpha_{7}-\mathrm{nAChR}$ [153]. Interestingly, during pregnancy $\alpha_{7}-\mathrm{nAChR}$ was shown to be downregulated in the oviduct, possibly as a protective mechanism against this complication [152]. Generally, smoking during pregnancy is associated with an increased risk for various complications. Nicotine exposure was shown to result in low birth weights, cognitive dysfunctions as well as impaired lung function of newborns. With prenatal nicotine exposure expression of $\alpha_{7}-n A C h R$ is enhanced in the neonatal lung [154]. Further, the risk of infant respiratory tract infections is supposed to be enhanced by in utero nicotine exposure, due to $\alpha_{7}$-nAChR-mediated influence on alveolar macrophages [155].

Pre-eclampsia is an anti-angiogenic state associated with high blood pressure and proteinuria that can occur during pregnancy. Interestingly, nicotine exposure was shown to reduce the risk of pre-eclampsia by reducing the placental production of soluble vascular endothelial growth factor receptor 1 and inducing placental growth factor, thereby inducing angiogenesis [156]. Additionally, activation of $\alpha_{7}-n A C h R$ seems to reduce placental cytokine production and thus further protects from pre-eclampsia [157].

In the male reproductive system, the presence of an NNCS was clearly shown for the testis, as ACh-synthesizing enzyme ChAT, transporters and ACh receptors were expressed in non-innervated testis parenchyma [158]. ChAT was also shown to be expressed in spermatozoa [159], and release of non-neuronal ACh was measured in the germinal epithelium [158]. For the prostate gland, activation of $\mathrm{mAChR}$ results in secretion of prostate fluids [160] as well as in contractile response which is being mediated via M3 mAChR in the mouse [161]. Further, prostate cells were shown to express the ACh-degrading enzymes AChE and butyrylcholinesterase [162].

Nicotine has negative effects on spermatogenesis and steroidogenesis; most interestingly, mice deficient for $\alpha_{7^{-}}$ nAChR produce sperm with impaired motility [163] and $\mathrm{mAChR}$ agonists increase sperm motility in humans [164]. Many effects of ACh in the male reproductive tract such as vaso-activity, sperm transport, muscle contrac- 
tion and cell secretion are mediated via mAChR [165]. However, more research in this area is needed to explore the exact functional influence of the NNCS and its possible role in reproductive system pathology.

\section{Immune System}

Already more than 80 years ago, ACh was reported to be present in ox blood (reviewed in Kawashima and Fujii [166]). However, only in 1993 were Kawashima et al. [167] able to convincingly demonstrate the presence of ACh in the human blood and that it was produced mainly by mononuclear leucocytes. The ACh-synthesizing enzyme ChAT is expressed predominantly by T cells (mainly by CD $4+\mathrm{T}$ helper cells) but also by dendritic cells, granulocytes, macrophages and mast cells [168]. Upon contact with antigen-presenting cells activated $\mathrm{T}$ cells show an increase in ChAT activity and enhanced ACh synthesis via $\mathrm{T}$ cell receptor/CD3-mediated and CD11amediated pathways [168]. It is not clear whether in immune cells ACh can be stored in vesicles as VAChT was not detectable. Thus, it is more likely that newly synthesized ACh is directly released upon requirement [169]. Recently, Fujii et al. [170] suggested that ACh release in $\mathrm{T}$ cells is at least partly mediated via mediatophore. Immune cells are able to express $\mathrm{mAChR}$ as well as nAChR subtypes; however, expression patterns of these receptors seem to vary between individual subjects [171]. M1 $\mathrm{mAChR}$ was shown to play a role in the early differentiation of CD8+ T cells [172], and M5 mAChR is upregulated after activation of $\mathrm{T}$ cells [168]. Numerous studies revealed that $\mathrm{mAChR}$ activation has pro-inflammatory effects in different cell types. Accordingly, activated mononuclear leucocytes from M1/M5 mAChR-deficient mice produced significantly less pro-inflammatory cytokines [173]. Further, mAChR stimulation increases the number of leucocytes in splenic venous blood [174]. In contrast, activation of $\mathrm{nAChR}$ has been reported to have anti-inflammatory effects and especially the $\alpha_{7}$-nAChR was thoroughly analysed regarding this point. In 2003, Wang et al. [175] were able to show that in macrophages $a_{7}-n A C h R$ stimulation leads to significant reduction in synthesis and release of tumour necrosis factor $\alpha$.

The anti-inflammatory effect of $\alpha_{7}$-nAChR stimulation was further confirmed in experimental sepsis, where $\alpha_{7}$-nAChR-deficient mice showed higher levels of splenic and circulating pro-inflammatory cytokines after application of lipopolysaccharide [175]. Electrical stimulation of the vagus nerve leads to inhibition of inflammation and protection of septic shock [176], a phenomenon that is mediated via the $\alpha_{7}$-nAChR [175] and termed as 'cholinergic anti-inflammatory pathway'. Since that work of Tracey and coworkers, the cholinergic anti-inflammatory pathway was extensively studied and broadly reviewed [177]. However, not only the $\alpha_{7}$-nAChR can influence inflammation as the blockage of $\mathrm{mAChR}$, especially $\mathrm{M} 3$ $\mathrm{mAChR}$, appears to protect from lipopolysaccharide-induced lung inflammation [178]. Further, ChAT-expressing B cells were shown to reduce the recruitment of neutrophils during sterile lipopolysaccharide-induced endotoxaemia. Generally, the NNCS of immune cells seems to play a role in the regulation of immune system function.

\section{Auto-Immune Diseases and Immunodeficiencies}

Mice which develop auto-immune symptoms of systemic lupus erythematosus showed an increased ACh content in blood, thymus and spleen [179].

Sjögren's syndrome is a systemic autoimmune disorder mainly targeting the salivary glands and lacrimal glands, resulting in dry mouth and dry eyes. One important trigger for the pathogenesis of Sjögren's syndrome is the production of auto-antibodies against M3 mAChR acting as an antagonist for this receptor, resulting in suppression of aquaporin 5 trafficking and subsequent impairment of fluid secretion [180].

Spontaneously hypertensive rats develop an immune deficiency with decline in $\mathrm{T}$ cell function. These rats showed reduced ACh content as well as reduced ChAT expression in mononuclear leucocytes, probably due to the observed T cell deficiency [181].

Human immunodeficiency virus infection is characterized by an uncontrolled immune overstimulation which subsequently leads to a state of immunodeficiency. Thus, early therapies in dampening the overactivation of the immune system are needed. In a proof-of-concept, placebo-based study, the AChE inhibitor pyridostigmine was shown to reduce the $\mathrm{T}$ cell overactivation in human immunodeficiency virus patients [182].

\section{Musculoskeletal System}

The musculoskeletal system includes bones, muscles, cartilage, ligaments, tendons and joints.

Also in bone the presence of cholinergic components was clearly demonstrated. Inkson et al. [183] reported about the production of $\mathrm{AChE}$ in osteoblasts which is believed to be involved in cell-matrix interaction in the bone. Our group was able to show that osteoblasts express 
all necessary components for the synthesis and release of ACh [184]. Further, nAChR and mAChR were identified also on primary bone cells, mesenchymal stem cells and osteoclasts [185].

\section{Fracture Healing and Osteoporosis}

Signalling via $\mathrm{nAChR}$ and $\mathrm{mAChR}$ is involved in bone mass turnover. In this regard the nAChR subunit $\alpha_{2}$ and the M3 mAChR appear to play important roles as nAChR subunit $\alpha_{2}$-deficient [186] and M3 mAChR-deficient mice $[187,188]$ both show an osteoporosis-like phenotype.

Smoking seems to be associated with a decrease in bone mass and a reduced capacity for fracture healing [185]. However, the effect of nicotine in this regard appears to be dose dependent as low nicotine concentrations induce osteoblast formation, high levels of nicotine on the other hand lead to desensitization of osteoblastic $\mathrm{nAChR}$, downregulation of osteoblasts and upregulation of osteoclasts [185]. Generally, the effect of nicotine on bone metabolism is controversially discussed, and more research in this field is definitely needed.

In the skeletal muscle, expression of the ACh-synthesizing enzyme CarAT was found in denervated extensor digitorum longus muscles of the rat [3]. Further, proliferating myoblasts were shown to synthesize and release an ACh-like compound [189].

Tenocytes of patella [190, 191], Achilles [192] and plantaris [193] tendons express ChAT and VAChT as well as M2 mAChR, and their expression and activity were shown to be enhanced under pathological conditions such as tendinosis, a non-inflammatory degenerative disorder.

Nicotine influences chondrocyte differentiation [194, 195]. Besides this, not much is known about the NNCS in the cartilage. Unpublished data from our laboratory, however, revealed that there is marked expression of the NNCS in the cartilage of patients with osteo-arthritis and rheumatoid arthritis.

In 2008, Grimsholm et al. [196] were able to show that ChAT and the $\alpha_{7}$-nAChR are present in the synovial tissue of the human knee joint. ChAT mRNA and protein were localized to fibroblast-like and macrophage-like cells as well as to some extent in blood vessel walls of the synovial sample, while $\alpha_{7}$-nAChR was mostly found in the synovial intimal lining layer [197]. Recently, our group could show that different $\mathrm{nAChR}$ and $\mathrm{mAChR}$ as well as CarAT, transporters, and ACh-degrading enzymes are present in the synovial tissue of the human joint [198].

Non-Neuronal Cholinergic System in Health and Disease
Rheumatoid arthritis (RA) is with $1 \%$ prevalence (female $>$ male) one of the most common inflammatory joint diseases. Currently, disease-modifying antirheumatic drugs, like methotrexate, are still the most common treatment used for patients with RA; however, side effects can be severe. Recently, also anti-tumour necrosis factor- $\alpha$ treatment was successfully introduced as new therapeutic strategy, but unfortunately only in $26-42 \%$ of patients this treatment is effective [199]. Thus, there is still great need for new therapeutic strategies in RA, and the NNCS could be a promising target for pharmacological intervention.

In patients with RA, ChAT expression was markedly pronounced, probably because of a higher number of macrophage-like and fibroblast-like cells in the synovial samples [196]. There is increasing evidence for the role of synovial fibroblasts in the pathology of RA. In vitro studies on these cells revealed an anti-inflammatory effect for $\mathrm{ACh}$ and nicotine in these cells which was mediated via $a_{7}$-nAChR [200]. This anti-inflammatory effect of nicotine was also confirmed in vivo as administration of nicotine led to amelioration of experimentally induced arthritis in mice [201,202]. Interestingly however, the effect of nicotine on arthritis seems to be strongly dependent on the mode and time point of application as well as the immune status of the cells [203]. The role of $\alpha_{7}$-nAChR in experimentally induced arthritis is however controversially discussed as in studies with $\alpha_{7}$-nAChR-deficient arthritic mice completely opposing results were obtained regarding disease progression by two different research groups [204,205]. Thus, more extensive research is needed on the influence of the NNCS on inflammation and progression of RA.

It was shown that the cholinesterase inhibitor neostigmine has promising analgesic effects in inflamed joints [206]. However, there is one study where neostigmine was applied as analgesic agent intra-articularly to the rabbit knee joint, leading to increased infiltration of immune cells, cell hyperplasia and hypertrophy [207]. Also here, mode and time point of application may be relevant for the effects observed. Generally, analgesia is an important aspect for RA treatment. The activation of several $\mathrm{nAChR}$ was reported to have an antinociceptive effect $[208,209]$. And also mAChR seem to play important roles in analgesia in arthritis [210], and especially M1 mAChR was involved in the modulation of inflammatory pain in the paw [211]. Thus, targeting the NNCS in RA could be beneficial not only in respect to inflammation but also regarding analgesic effects. 
Table 1. NNCS components involved in pathological conditions, summarized for the different organ systems

\begin{tabular}{|c|c|}
\hline \multicolumn{2}{|l|}{ Integumentary system } \\
\hline Atopic dermatitis & ACh $[23,24]$ \\
\hline Vitiligo & AChE [28] \\
\hline Mal de Meleda & SLURP- 1 and $\alpha_{7}$ \\
\hline Psoriasis & SLURP-2 and $\alpha_{3}[30,31]$ \\
\hline Skin cancer & $\alpha_{7}[38]$ \\
\hline Cutaneous wound healing & SLURP-1, SLURP-2 and nAChR [39] \\
\hline \multicolumn{2}{|l|}{ Respiratory system } \\
\hline Asthma and COPD & ACh $[47,49]$, AChE and M1-3 [47] \\
\hline Lung cancer & ACh [52], CTL1 and CTL2 [54], CTL4 [53], $\alpha_{7}$ [55], M3 [56] \\
\hline Cystic fibrosis & $\operatorname{ACh}[61], \operatorname{mAChR}[62], a_{7}[63,64]$ \\
\hline Gastro-oesophageal reflux disease & ACh [85], ChAT, VAChT and OCT1 [86] \\
\hline Gastric and duodenal ulcers & ACh, M1 and M3 [89-91] \\
\hline Colon cancer & M3 $[96,97], \alpha_{7}[98,99]$, CTL1 - $5[53]$, SLURP-1 $[98,100]$ \\
\hline Inflammatory bowel disease & AChE [101], M2 and ChAT [104], $\alpha_{3}[105], \alpha_{7}[106], \alpha_{5}[108]$ \\
\hline Type 2 diabetes and pancreatitis & M3 $[112,115]$, nAChR $[114]$ \\
\hline \multicolumn{2}{|l|}{ Urinary system } \\
\hline Acute/chronic kidney disease & $\mathrm{nAChR}[132], \alpha_{7}[124,135,136]$ \\
\hline Ischaemia-reperfusion & $\alpha_{7}[126,133,134]$ \\
\hline Overactive bladder syndrome & mAChR $[127,138-140]$ \\
\hline Bladder outlet obstruction & M3 [145] \\
\hline \multicolumn{2}{|l|}{ Reproductive system } \\
\hline Tubal ectopic pregnancy and pre-eclampsia & $\alpha_{7}[152-155,157]$ \\
\hline Tendinosis & ChAT, VAChT and M2 $[190,191]$ \\
\hline Rheumatoid arthritis & $\operatorname{ChAT}[196], a_{7}[200,204,205]$ \\
\hline
\end{tabular}

\section{Conclusion}

Taken together, non-neuronal ACh is produced by cells of various tissues and organ systems and acts in an autocrine and paracrine way on $\mathrm{nAChR}$ and $\mathrm{mAChR}$ present on the ACh-producing or neighbouring effector cells. In the non-diseased state the NNCS plays a role in many important biological and physiological processes like cell growth, adhesion, migration and differentiation. Thus, impairment or dysregulation of the NNCS and its functions can influence the pathogenesis and pathology of various diseases. Table 1 is summarizing the diseases mentioned in this review and the NNCS components involved in their pathology. In the last few years, studies on NNCS expression patterns and research on gene-deficient mice gave further insights into the diverse functions and importance of NNSC components in maintaining homeostasis. For some diseases like e.g. overactive bladder syndrome, pharmacological intervention of cholinergic signalling became the therapy of choice. However, there are tissue and organ systems for which the NNCS has not yet been extensively studied and/or 
the effect of cholinergic signalling is still controversially discussed. Thus, more research on the presence, the expression pattern and distinct functions of the NNCS is definitely needed. Regarding the importance of NNCS functions and the impact of pharmacological intervention for some disorders, components of the NNCS are a promising target for the development of new therapeutic strategies.

\section{Acknowledgement}

The authors Janet Beckmann and Katrin Susanne Lips are supported by grants from LOEWE research focus 'Non-neuronal cholinergic systems', funded by the HMWK, and DFG SFB/TR 79 project $\mathrm{B}$, respectively.

\section{Disclosure Statement}

The authors declare that there are no conflicts of interest.

\section{References}

1 Wessler I, Kirkpatrick CJ, Racke K: The cholinergic 'pitfall': acetylcholine, a universal cell molecule in biological systems, including humans. Clin Exp Pharmacol Physiol 1999;26: 198-205.

-2 Wessler I, Kilbinger H, Bittinger F, Unger R, Kirkpatrick CJ: The non-neuronal cholinergic system in humans: expression, function and pathophysiology. Life Sci 2003;72:2055-2061.

-3 Tucek S: The synthesis of acetylcholine in skeletal muscles of the rat. J Physiol 1982;322: 53-69.

-4 Lips KS, Wunsch J, Zarghooni S, Bschleipfer T, Schukowski K, Weidner W, Wessler I, Schwantes U, Koepsell H, Kummer W: Acetylcholine and molecular components of its synthesis and release machinery in the urothelium. Eur Urol 2007;51:1042-1053.

5 Okuda T, Haga T: High-affinity choline transporter. Neurochem Res 2003;28:483-488.

6 Haberberger RV, Pfeil U, Lips KS, Kummer W: Expression of the high-affinity choline transporter, CHT1, in the neuronal and nonneuronal cholinergic system of human and rat skin. J Invest Dermatol 2002;119:943-948.

-7 Pfeil U, Haberberger RV, Lips KS, Eberling L, Grau V, Kummer W: Expression of the highaffinity choline transporter CHT1 in epithelia. Life Sci 2003;72:2087-2090.

8 Lips KS, Pfeil U, Reiners K, Rimasch C, Kuchelmeister K, Braun-Dullaeus RC, Haberberger RV, Schmidt R, Kummer W: Expression of the high-affinity choline transporter CHT1 in rat and human arteries. J Histochem Cytochem 2003;51:1645-1654.

$\checkmark 9$ Yamada T, Inazu M, Tajima H, Matsumiya T: Functional expression of choline transporterlike protein 1 (CTL1) in human neuroblastoma cells and its link to acetylcholine synthesis. Neurochem Int 2011;58:354-365.

-10 Traiffort E, Ruat M, O’Regan S, Meunier FM: Molecular characterization of the family of choline transporter-like proteins and their splice variants. J Neurochem 2005;92:11161125.
11 Erickson JD, Varoqui H, Schafer MK, Modi W, Diebler MF, Weihe E, Rand J, Eiden LE, Bonner TI, Usdin TB: Functional identification of a vesicular acetylcholine transporter and its expression from a 'cholinergic' gene locus. J Biol Chem 1994;269:21929-21932.

12 Kummer W, Lips KS, Pfeil U: The epithelial cholinergic system of the airways. Histochem Cell Biol 2008;130:219-234.

13 Lips KS, Volk C, Schmitt BM, Pfeil U, Arndt P, Miska D, Ermert L, Kummer W, Koepsell $\mathrm{H}$ : Polyspecific cation transporters mediate luminal release of acetylcholine from bronchial epithelium. Am J Respir Cell Mol Biol 2005;33:79-88.

14 Koepsell H, Lips K, Volk C: Polyspecific organic cation transporters: structure, function, physiological roles, and biopharmaceutical implications. Pharm Res 2007;24:1227-1251.

15 Israel M, Dunant Y: Acetylcholine release. Reconstitution of the elementary quantal mechanism. J Physiol (Paris) 1998;92:123-128.

16 Hurst R, Rollema H, Bertrand D: Nicotinic acetylcholine receptors: from basic science to therapeutics. Pharmacol Ther 2013;137:2254.

17 De Jonge WJ, van der Zanden EP, The FO, Bijlsma MF, van Westerloo DJ, Bennink RJ, Berthoud HR, Uematsu S, Akira S, van den Wijngaard RM, Boeckxstaens GE: Stimulation of the vagus nerve attenuates macrophage activation by activating the JAK2STAT3 signaling pathway. Nat Immunol 2005;6:844-851.

-18 Dasgupta P, Kinkade R, Joshi B, Decook C, Haura E, Chellappan S: Nicotine inhibits apoptosis induced by chemotherapeutic drugs by up-regulating xiap and survivin. Proc Natl Acad Sci USA 2006; 103:6332-6337.

19 Fischer J, Bouadjar B, Heilig R, Huber M, Lefevre C, Jobard F, Macari F, Bakija-Konsuo A, Ait-Belkacem F, Weissenbach J, Lathrop M, Hohl D, Prud'homme JF: Mutations in the gene encoding SLURP-1 in mal de Meleda. Hum Mol Genet 2001;10:875-880.

20 Wess J: Molecular biology of muscarinic acetylcholine receptors. Crit Rev Neurobiol 1996;10:69-99.
21 Lanzafame AA, Christopoulos A, Mitchelson F: Cellular signaling mechanisms for muscarinic acetylcholine receptors. Receptors Channels 2003;9:241-260.

22 Grando SA, Kist DA, Qi M, Dahl MV: Human keratinocytes synthesize, secrete, and degrade acetylcholine. J Invest Dermatol 1993;101: 32-36.

23 Grando SA, Pittelkow MR, Schallreuter KU: Adrenergic and cholinergic control in the biology of epidermis: physiological and clinical significance. J Invest Dermatol 2006;126: 1948-1965.

24 Wessler I, Reinheimer T, Kilbinger H, Bittinger F, Kirkpatrick CJ, Saloga J, Knop J: Increased acetylcholine levels in skin biopsies of patients with atopic dermatitis. Life Sci 2003; 72:2169-2172.

25 Raap U, Werfel T, Jaeger B, Schmid-Ott G: Atopic dermatitis and psychological stress (in German). Hautarzt 2003;54:925-929.

-26 Amano H, Negishi I, Akiyama H, Ishikawa O: Psychological stress can trigger atopic dermatitis in nc/nga mice: an inhibitory effect of corticotropin-releasing factor. Neuropsychopharmacology 2008;33:566-573.

27 Curtis BJ, Radek KA: Cholinergic regulation of keratinocyte innate immunity and permeability barrier integrity: new perspectives in epidermal immunity and disease. J Invest Dermatol 2012;132:28-42.

28 Schallreuter KU, Elwary SM, Gibbons NC, Rokos H, Wood JM: Activation/deactivation of acetylcholinesterase by $\mathrm{H}_{2} \mathrm{O}_{2}$ : more evidence for oxidative stress in vitiligo. Biochem Biophys Res Commun 2004;315:502-508.

29 Chimienti F, Hogg RC, Plantard L, Lehmann C, Brakch N, Fischer J, Huber M, Bertrand D, Hohl D: Identification of SLURP-1 as an epidermal neuromodulator explains the clinical phenotype of mal de Meleda. Hum Mol Genet 2003;12:3017-3024.

30 Tsuji H, Okamoto K, Matsuzaka Y, Iizuka H, Tamiya G, Inoko H: Slurp-2, a novel member of the human Ly-6 superfamily that is up-regulated in psoriasis vulgaris. Genomics 2003; 81:26-33.
Non-Neuronal Cholinergic System in Health and Disease 
-31 Arredondo J, Chernyavsky AI, Jolkovsky DL, Webber RJ, Grando SA: Slurp-2: a novel cholinergic signaling peptide in human mucocutaneous epithelium. J Cell Physiol 2006;208: 238-245.

32 Grando SA: Pemphigus autoimmunity: hypotheses and realities. Autoimmunity 2012; 45:7-35.

- 33 Baroni A, Buommino E, Ruocco E, Petrazzuolo M, De Filippis A, Satriano RA, Ruocco V, Cozza V, Tufano MA: Captopril modulates acetylcholinesterase in human keratinocytes. Arch Dermatol Res 2011;303:491-497.

34 Hagforsen E: The cutaneous non-neuronal cholinergic system and smoking related dermatoses: studies of the psoriasis variant palmoplantar pustulosis. Life Sci 2007;80:22272234.

35 Ortiz A, Grando SA: Smoking and the skin. Int J Dermatol 2012;51:250-262.

- 36 De Hertog SA, Wensveen CA, Bastiaens MT, Kielich CJ, Berkhout MJ, Westendorp RG, Vermeer BJ, Bouwes Bavinck JN, Leiden Skin Cancer Study: Relation between smoking and skin cancer. J Clin Oncol 2001;19:231-238.

- 37 Anderson LA, Lauria C, Romano N, Brown EE, Whitby D, Graubard BI, Li Y, Messina A, Gafa L, Vitale F, Goedert JJ: Risk factors for classical Kaposi sarcoma in a populationbased case-control study in Sicily. Cancer Epidemiol Biomarkers Prev 2008; 17:34353443.

- 38 Arredondo J, Chernyavsky AI, Jolkovsky DL, Pinkerton KE, Grando SA: Receptor-mediated tobacco toxicity: cooperation of the Ras/ Raf-1/MEK1/ERK and JAK-2/STAT-3 pathways downstream of alpha7 nicotinic receptor in oral keratinocytes. FASEB J 2006;20: 2093-2101.

-39 Chernyavsky AI, Marchenko S, Phillips C, Grando SA: Auto/paracrine nicotinergic peptides participate in cutaneous stress response to wounding. Dermatoendocrinology 2012;4: 324-330.

40 Buels KS, Fryer AD: Muscarinic receptor antagonists: effects on pulmonary function. Handb Exp Pharmacol 2012;208:317-341.

-41 Arias HR, Richards VE, Ng D, Ghafoori ME, Le V, Mousa SA: Role of non-neuronal nicotinic acetylcholine receptors in angiogenesis. Int J Biochem Cell Biol 2009;41:1441-1451.

42 Klapproth H, Reinheimer T, Metzen J, Munch M, Bittinger F, Kirkpatrick CJ, Hohle KD, Schemann M, Racke K, Wessler I: Non-neuronal acetylcholine, a signalling molecule synthesized by surface cells of rat and man. Naunyn-Schmiedeberg's Arch Pharmacol 1997; 355:515-523.

43 Carlisle DL, Hopkins TM, Gaither-Davis A, Silhanek MJ, Luketich JD, Christie NA, Siegfried JM: Nicotine signals through muscletype and neuronal nicotinic acetylcholine receptors in both human bronchial epithelial cells and airway fibroblasts. Respir Res 2004; $5: 27$.
44 Klein MK, Haberberger RV, Hartmann P, Faulhammer P, Lips KS, Krain B, Wess J, Kummer W, Konig P: Muscarinic receptor subtypes in cilia-driven transport and airway epithelial development. Eur Respir J 2009;33: 1113-1121.

45 Reinheimer T, Munch M, Bittinger F, Racke K, Kirkpatrick CJ, Wessler I: Glucocorticoids mediate reduction of epithelial acetylcholine content in the airways of rats and humans. Eur J Pharmacol 1998;349:277-284.

46 Milara J, Serrano A, Peiro T, Gavalda A, Miralpeix M, Morcillo EJ, Cortijo J: Aclidinium inhibits human lung fibroblast to myofibroblast transition. Thorax 2012;67:229-237.

47 Milara J, Serrano A, Peiro T, Artigues E, Gavalda A, Miralpeix M, Morcillo EJ, Cortijo J: Aclidinium inhibits cigarette smoke-induced lung fibroblast-to-myofibroblast transition. Eur Respir J 2013;41:1264-1274.

48 Lips KS, Luhrmann A, Tschernig T, Stoeger T, Alessandrini F, Grau V, Haberberger RV, Koepsell H, Pabst R, Kummer W: Down-regulation of the non-neuronal acetylcholine synthesis and release machinery in acute allergic airway inflammation of rat and mouse. Life Sci 2007;80:2263-2269.

49 Gwilt CR, Donnelly LE, Rogers DF: The nonneuronal cholinergic system in the airways: an unappreciated regulatory role in pulmonary inflammation? Pharmacol Ther 2007; 115:208-222.

50 The 2004 United States Surgeon General's Report: the health consequences of smoking. New South Wales Publ Health Bull 2004;15: 107.

51 Singh S, Pillai S, Chellappan S: Nicotinic acetylcholine receptor signaling in tumor growth and metastasis. J Oncol 2011;2011:456743.

52 Song P, Spindel ER: Basic and clinical aspects of non-neuronal acetylcholine: expression of non-neuronal acetylcholine in lung cancer provides a new target for cancer therapy. J Pharmacol Sci 2008;106:180-185.

53 Song P, Rekow SS, Singleton CA, Sekhon HS, Dissen GA, Zhou M, Campling B, Lindstrom J, Spindel ER: Choline transporter-like protein 4 (CTL4) links to non-neuronal acetylcholine synthesis. J Neurochem 2013;126: 451-461.

54 Nakamura T, Fujiwara R, Ishiguro N, Oyabu M, Nakanishi T, Shirasaka Y, Maeda T, Tamai I: Involvement of choline transporter-like proteins, CTL1 and CTL2, in glucocorticoidinduced acceleration of phosphatidylcholine synthesis via increased choline uptake. Biol Pharm Bull 2010;33:691-696.

55 Grozio A, Paleari L, Catassi A, Servent D, Cilli M, Piccardi F, Paganuzzi M, Cesario A, Granone P, Mourier G, Russo P: Natural agents targeting the alpha7-nicotinic-receptor in NSCLC: a promising prospective in anti-cancer drug development. Int J Cancer 2008;122: 1911-1915.
Spindel ER: Muscarinic receptor agonists and antagonists: effects on cancer. Handb Exp Pharmacol 2012;208:451-468.

-57 Thorgeirsson TE, Geller F, Sulem P, Rafnar T, Wiste A, Magnusson KP, Manolescu A, Thorleifsson $G$, Stefansson $H$, Ingason A, Stacey SN, Bergthorsson JT, Thorlacius S, Gudmundsson J, Jonsson T, Jakobsdottir M, Saemundsdottir J, Olafsdottir O, Gudmundsson LJ, Bjornsdottir G, Kristjansson K, Skuladottir H, Isaksson HJ, Gudbjartsson T, Jones GT, Mueller T, Gottsater A, Flex A, Aben KK, de Vegt F, Mulders PF, Isla D, Vidal MJ, Asin L, Saez B, Murillo L, Blondal T, Kolbeinsson H, Stefansson JG, Hansdottir I, Runarsdottir V, Pola R, Lindblad B, van Rij AM, Dieplinger B, Haltmayer M, Mayordomo JI, Kiemeney LA, Matthiasson SE, Oskarsson $\mathrm{H}$, Tyrfingsson $\mathrm{T}$, Gudbjartsson DF, Gulcher JR, Jonsson S, Thorsteinsdottir U, Kong A, Stefansson K: A variant associated with nicotine dependence, lung cancer and peripheral arterial disease. Nature 2008;452:638-642.

58 Hung RJ, McKay JD, Gaborieau V, Boffetta P, Hashibe M, Zaridze D, Mukeria A, SzeszeniaDabrowska N, Lissowska J, Rudnai P, Fabianova E, Mates D, Bencko V, Foretova L, Janout V, Chen C, Goodman G, Field JK, Liloglou T, Xinarianos G, Cassidy A, McLaughlin J, Liu G, Narod S, Krokan HE, Skorpen F, Elvestad MB, Hveem K, Vatten L, Linseisen J, Clavel-Chapelon F, Vineis P, Bueno-de-Mesquita $\mathrm{HB}$, Lund E, Martinez C, Bingham S, Rasmuson T, Hainaut P, Riboli E, Ahrens W, Benhamou S, Lagiou P, Trichopoulos D, Holcatova I, Merletti F, Kjaerheim K, Agudo A, Macfarlane G, Talamini R, Simonato L, Lowry R, Conway DI, Znaor A, Healy C, Zelenika D, Boland A, Delepine M, Foglio M, Lechner D, Matsuda F, Blanche H, Gut I, Heath S, Lathrop M, Brennan P: A susceptibility locus for lung cancer maps to nicotinic acetylcholine receptor subunit genes on $15 \mathrm{q} 25$. Nature 2008;452:633-637.

59 Chikova A, Bernard HU, Shchepotin IB, Grando SA: New associations of the genetic polymorphisms in nicotinic receptor genes with the risk of lung cancer. Life Sci 2012;91: 1103-1108.

-60 Riordan JR, Rommens JM, Kerem B, Alon N, Rozmahel R, Grzelczak Z, Zielenski J, Lok S, Plavsic N, Chou JL, et al: Identification of the cystic fibrosis gene: cloning and characterization of complementary DNA. Science 1989; 245:1066-1073.

61 Wessler I, Bittinger F, Kamin W, Zepp F, Meyer E, Schad A, Kirkpatrick CJ: Dysfunction of the non-neuronal cholinergic system in the airways and blood cells of patients with cystic fibrosis. Life Sci 2007;80:2253-2258.

62 Billet A, Luo Y, Balghi H, Hanrahan JW: Role of tyrosine phosphorylation in the muscarinic activation of the cystic fibrosis transmembrane conductance regulator (CFTR). J Biol Chem 2013;288:21815-21823. 
63 Maouche K, Medjber K, Zahm JM, Delavoie F, Terryn C, Coraux C, Pons S, Cloez-Tayarani I, Maskos U, Birembaut P, Tournier JM: Contribution of alpha7 nicotinic receptor to airway epithelium dysfunction under nicotine exposure. Proc Natl Acad Sci USA 2013; 110:4099-4104.

-64 Greene CM, Ramsay H, Wells RJ, O’Neill SJ, McElvaney NG: Inhibition of Toll-like receptor 2-mediated interleukin-8 production in cystic fibrosis airway epithelial cells via the alpha7-nicotinic acetylcholine receptor. Mediat Inflamm 2010;2010:423241.

- 65 Rana OR, Schauerte P, Kluttig R, Schroder JW, Koenen RR, Weber C, Nolte KW, Weis J, Hoffmann R, Marx N, Saygili E: Acetylcholine as an age-dependent non-neuronal source in the heart. Auton Neurosci Basic Clin 2010;156:82-89.

66 Abramochkin DV, Borodinova AA, Rosenshtraukh LV, Nikolsky EE: Both neuronal and non-neuronal acetylcholine take part in non-quantal acetylcholine release in the rat atrium. Life Sci 2012;91:1023-1026.

-67 Slavikova J, Tucek S: Choline acetyltransferase in the heart of adult rats. Pflügers Arch 1982;392:225-229.

-68 Dvorakova M, Lips KS, Bruggmann D, Slavikova J, Kuncova J, Kummer W: Developmental changes in the expression of nicotinic acetylcholine receptor alpha-subunits in the rat heart. Cell Tissue Res 2005;319:201-209.

-69 Shi H, Wang H, Wang Z: Identification and characterization of multiple subtypes of muscarinic acetylcholine receptors and their physiological functions in canine hearts. Mol Pharmacol 1999;55:497-507.

-70 Harvey RD: Muscarinic receptor agonists and antagonists: effects on cardiovascular function. Handb Exp Pharmacol 2012;208:299316.

-71 Haberberger RV, Bodenbenner M, Kummer $\mathrm{W}$ : Expression of the cholinergic gene locus in pulmonary arterial endothelial cells. Histochem Cell Biol 2000;113:379-387.

-72 Komori K, Suzuki H: Heterogeneous distribution of muscarinic receptors in the rabbit saphenous artery. Br J Pharmacol 1987;92: 657-664.

73 Walch L, Gascard JP, Dulmet E, Brink C, Norel X: Evidence for a M(1) muscarinic receptor on the endothelium of human pulmonary veins. Br J Pharmacol 2000;130:73-78.

-74 Phillips JK, Vidovic M, Hill CE: Variation in mRNA expression of alpha-adrenergic, neurokinin and muscarinic receptors amongst four arteries of the rat. J Auton Nerv Syst 1997;62:85-93.

-75 Kirkpatrick CJ, Bittinger F, Unger RE, Kriegsmann J, Kilbinger H, Wessler I: The non-neuronal cholinergic system in the endothelium: evidence and possible pathobiological significance. Jpn J Pharmacol 2001;85:24-28.

76 Li XW, Wang H: Non-neuronal nicotinic alpha 7 receptor, a new endothelial target for revascularization. Life Sci 2006;78:18631870.
77 Heeschen C, Weis M, Aicher A, Dimmeler S, Cooke JP: A novel angiogenic pathway mediated by non-neuronal nicotinic acetylcholine receptors. J Clin Invest 2002;110:527-536.

78 Wu JC, Chruscinski A, De Jesus Perez VA, Singh H, Pitsiouni M, Rabinovitch M, Utz PJ, Cooke JP: Cholinergic modulation of angiogenesis: role of the 7 nicotinic acetylcholine receptor. J Cell Biochem 2009;108:433-446.

79 Kakinuma Y, Furihata M, Akiyama T, Arikawa M, Handa T, Katare RG, Sato T: Donepezil, an acetylcholinesterase inhibitor against Alzheimer's dementia, promotes angiogenesis in an ischemic hindlimb model. J Mol Cell Cardiol 2010;48:680-693.

-80 Ferdinandy P, Schulz R, Baxter GF: Interaction of cardiovascular risk factors with myocardial ischemia/reperfusion injury, preconditioning, and postconditioning. Pharmacol Rev 2007;59:418-458.

81 Pan Z, Guo Y, Qi H, Fan K, Wang S, Zhao H, Fan Y, Xie J, Guo F, Hou Y, Wang N, Huo R, Zhang Y, Liu Y, Du Z: M3 subtype of muscarinic acetylcholine receptor promotes cardioprotection via the suppression of miR-376b5p. PloS One 2012;7:e32571.

82 Lee J, Cooke JP: Nicotine and pathological angiogenesis. Life Sci 2012;91:1058-1064.

83 Heeschen C, Jang JJ, Weis M, Pathak A, Kaji S, Hu RS, Tsao PS, Johnson FL, Cooke JP: Nicotine stimulates angiogenesis and promotes tumor growth and atherosclerosis. Nat Med 2001;7:833-839.

84 Nguyen VT, Hall LL, Gallacher G, Ndoye A, Jolkovsky DL, Webber RJ, Buchli R, Grando SA: Choline acetyltransferase, acetylcholinesterase, and nicotinic acetylcholine receptors of human gingival and esophageal epithelia. J Dent Res 2000;79:939-949.

85 Saegusa Y, Takeda H, Muto S, Oridate N, Nakagawa K, Sadakane C, Nahata M, Harada Y, Iizuka M, Hattori T, Asaka M: Decreased motility of the lower esophageal sphincter in a rat model of gastroesophageal reflux disease may be mediated by reductions of serotonin and acetylcholine signaling. Biol Pharm Bull 2011; 34:704-711.

86 Wolf-Johnston AS, Hanna-Mitchell AT, Buffington CA, Shinde S, Roppolo JR, Mayer $\mathrm{E}$, Birder LA: Alterations in the non-neuronal acetylcholine synthesis and release machinery in esophageal epithelium. Life Sci 2012;91: 1065-1069.

87 Harrington AM, Hutson JM, Southwell BR: Cholinergic neurotransmission and muscarinic receptors in the enteric nervous system. Prog Histochem Cytochem 2010;44:173-202.

88 Ruggieri MR, Braverman AS: Gastric body cholinergic contractile signal transduction in M2 and M3 receptor knockout mice. J Receptor Signal Transduct Res 2013;33:249-254.

89 Xie G, Drachenberg C, Yamada M, Wess J, Raufman JP: Cholinergic agonist-induced pepsinogen secretion from murine gastric chief cells is mediated by M1 and M3 muscarinic receptors. Am J Physiol Gastrointest Liver Physiol 2005;289:G521-G529.
90 Aihara T, Nakamura Y, Taketo MM, Matsui $\mathrm{M}$, Okabe S: Cholinergically stimulated gastric acid secretion is mediated by $\mathrm{M}(3)$ and $\mathrm{M}(5)$ but not M(1) muscarinic acetylcholine receptors in mice. Am J Physiol Gastrointest Liver Physiol 2005;288:G1199-G1207.

-91 Raufman JP: Peptic activity and gastroduodenal mucosal damage. Yale J Biol Med 1996;69:85-90.

92 Nathanson NM: Synthesis, trafficking, and localization of muscarinic acetylcholine receptors. Pharmacol Ther 2008;119:33-43.

93 Cameron HL, Perdue MH: Muscarinic acetylcholine receptor activation increases transcellular transport of macromolecules across mouse and human intestinal epithelium in vitro. Neurogastroenterol Motil 2007;19:47-56.

94 Gautron L, Rutkowski JM, Burton MD, Wei W, Wan Y, Elmquist JK: Neuronal and nonneuronal cholinergic structures in the mouse gastrointestinal tract and spleen. J Comp Neurol 2013;521:3741-3767.

-95 Yajima T, Inoue R, Matsumoto M, Yajima $\mathrm{M}$ : Non-neuronal release of ACh plays a key role in secretory response to luminal propionate in rat colon. J Physiol 2011;589:953962.

96 Yang WL, Frucht H: Cholinergic receptor up-regulates COX-2 expression and prostaglandin $\mathrm{E}(2)$ production in colon cancer cells. Carcinogenesis 2000;21:1789-1793.

$\$ 97$ Raufman JP, Cheng K, Saxena N, Chahdi A Belo A, Khurana S, Xie G: Muscarinic receptor agonists stimulate matrix metalloproteinase 1-dependent invasion of human colon cancer cells. Biochem Biophys Res Commun 2011;415:319-324.

-98 Pettersson A, Nilsson L, Nylund G, Khorram-Manesh A, Nordgren S, Delbro DS: Is acetylcholine an autocrine/paracrine growth factor via the nicotinic alpha7-receptor subtype in the human colon cancer cell line HT29? Eur J Pharmacol 2009;609:27-33.

99 Cucina A, Dinicola S, Coluccia P, Proietti S, D’Anselmi F, Pasqualato A, Bizzarri M: Nicotine stimulates proliferation and inhibits apoptosis in colon cancer cell lines through activation of survival pathways. J Surg Res 2012;178:233-241.

100 Pettersson A, Nordlander S, Nylund G, Khorram-Manesh A, Nordgren S, Delbro DS: Expression of the endogenous, nicotinic acetylcholine receptor ligand, SLURP-1, in human colon cancer. Auton Autac Pharmacol 2008;28:109-116.

101 Maharshak N, Shenhar-Tsarfaty S, Aroyo N, Orpaz N, Guberman I, Canaani J, Halpern Z, Dotan I, Berliner S, Soreq H: MicroRNA-132 modulates cholinergic signaling and inflammation in human inflammatory bowel disease. Inflamm Bowel Dis 2013;19:13461353.

-102 Hilsden RJ, Hodgins DC, Timmer A, Sutherland LR: Helping patients with Crohn's disease quit smoking. Am J Gastroenterol 2000; 95:352-358.
Non-Neuronal Cholinergic System in Health and Disease
Pharmacology 2013;92:286-302 DOI: $10.1159 / 000355835$ 
103 De Jonge WJ, Ulloa L: The alpha7 nicotinic 115 Samuel I, Zaheer S, Fisher RA, Zaheer A: acetylcholine receptor as a pharmacological target for inflammation. Br J Pharmacol 2007;151:915-929.

104 Jonsson M, Norrgard O, Forsgren S: Presence of a marked nonneuronal cholinergic system in human colon: study of normal colon and colon in ulcerative colitis. Inflamm Bowel Dis 2007;13:1347-1356.

105 Richardson CE, Morgan JM, Jasani B, Green JT, Rhodes J, Williams GT, Lindstrom J, Wonnacott S, Peel S, Thomas GA: Effect of smoking and transdermal nicotine on colonic nicotinic acetylcholine receptors in ulcerative colitis. Q J Med 2003;96:57-65.

106 Ghia JE, Blennerhassett P, Deng Y, Verdu EF, Khan WI, Collins SM: Reactivation of inflammatory bowel disease in a mouse model of depression. Gastroenterology 2009; 136:2280-2288.

107 Lakhan SE, Kirchgessner A: Anti-inflammatory effects of nicotine in obesity and ulcerative colitis. J Transl Med 2011;9:129.

-108 Orr-Urtreger A, Kedmi M, Rosner S, Karmeli F, Rachmilewitz D: Increased severity of experimental colitis in alpha 5 nicotinic acetylcholine receptor subunit-deficient mice. Neuroreport 2005;16:1123-1127.

109 Gautam D, Han SJ, Heard TS, Cui Y, Miller G, Bloodworth L, Wess J: Cholinergic stimulation of amylase secretion from pancreatic acinar cells studied with muscarinic acetylcholine receptor mutant mice. J Pharmacol Exp Ther 2005;313:995-1002.

110 Chowdhury P, Bose C, Udupa KB: Nicotineinduced proliferation of isolated rat pancreatic acinar cells: effect on cell signalling and function. Cell Prolif 2007;40:125-141.

111 Phillips PA, Yang L, Shulkes A, Vonlaufen A, Poljak A, Bustamante S, Warren A, Xu Z, Guilhaus M, Pirola R, Apte MV, Wilson JS: Pancreatic stellate cells produce acetylcholine and may play a role in pancreatic exocrine secretion. Proc Natl Acad Sci USA 2010;107:17397-17402.

-112 Gautam D, Han SJ, Hamdan FF, Jeon J, Li B, Li JH, Cui Y, Mears D, Lu H, Deng C, Heard T, Wess J: A critical role for beta cell M3 muscarinic acetylcholine receptors in regulating insulin release and blood glucose homeostasis in vivo. Cell Metab 2006;3:449461.

113 Rodriguez-Diaz R, Dando R, Jacques-Silva MC, Fachado A, Molina J, Abdulreda MH, Ricordi C, Roper SD, Berggren PO, Caicedo A: Alpha cells secrete acetylcholine as a nonneuronal paracrine signal priming beta cell function in humans. Nat Med 2011;17:888892.

114 Talamini G, Bassi C, Falconi M, Sartori N, Salvia R, Rigo L, Castagnini A, Di Francesco V, Frulloni L, Bovo P, Vaona B, Angelini G, Vantini I, Cavallini G, Pederzoli P: Alcohol and smoking as risk factors in chronic pancreatitis and pancreatic cancer. Dig Dis Sci 1999;44:1303-1311. Cholinergic receptor induction and JNK activation in acute pancreatitis. Am J Surg 2003;186:569-574.

116 Maeda S, Jun JG, Kuwahara-Otani S, Tanaka K, Hayakawa T, Seki M: Non-neuronal expression of choline acetyltransferase in the rat kidney. Life Sci 2011;89:408-414.

117 Vander AJ: Effects of acetylcholine, atropine, and physostigmine on renal function in the dog. Am J Physiol 1964;206:492-498.

118 Harvey RB: Effects of acetylcholine infused into renal artery of dogs. Am J Physiol 1966; 211:487-492.

119 McArdle S, Garg LC, Crews FT: Cholinergic receptors in renal medullary collecting duct cells. J Pharmacol Exp Ther 1989;248:12-16.

120 Mohuczy-Dominiak D, Garg LC: Characterization of cholinergic receptors in MadinDarby canine kidney cells. J Am Soc Nephrol 1992;3:170-181.

-121 Nadler LS, Kumar G, Hinds TR, Migeon JC, Nathanson NM: Asymmetric distribution of muscarinic acetylcholine receptors in Madin-Darby canine kidney cells. Am J Physiol 1999;277:C1220-C1228.

122 Nitschke R, Henger A, Ricken S, Muller V, Kottgen M, Bek M, Pavenstadt H: Acetylcholine increases the free intracellular calcium concentration in podocytes in intact rat glomeruli via muscarinic $\mathrm{M}(5)$ receptors. J Am Soc Nephrol 2001;12:678-687.

123 Robey RB, Ruiz OS, Baniqued J, Mahmud D, Espiritu DJ, Bernardo AA, Arruda JA: SFKs, Ras, and the classic MAPK pathway couple muscarinic receptor activation to increased $\mathrm{Na}-\mathrm{HCO}(3)$ cotransport activity in renal epithelial cells. Am J Physiol Renal Physiol 2001;280:F844-F850.

124 Rezonzew G, Chumley P, Feng W, Hua P, Siegal GP, Jaimes EA: Nicotine exposure and the progression of chronic kidney disease: role of the alpha7-nicotinic acetylcholine receptor. Am J Physiol Renal Physiol 2012; 303:F304-F312.

125 el-Mas MM, el-Gowilly SM, Gohar EY, Ghazal AR, Abdel-Rahman AA: Estrogen dependence of the renal vasodilatory effect of nicotine in rats: role of alpha7 nicotinic cholinergic receptor/eNOS signaling. Life Sci 2011;88:187-193.

-126 Yeboah MM, Xue X, Javdan M, Susin M, Metz CN: Nicotinic acetylcholine receptor expression and regulation in the rat kidney after ischemia-reperfusion injury. Am J Physiol Renal Physiol 2008;295:F654-F661.

127 Sellers DJ, Chess-Williams R: Muscarinic agonists and antagonists: effects on the urinary bladder. Handb Exp Pharmacol 2012; 208:375-400.

128 Yoshida M, Inadome A, Maeda Y, Satoji Y, Masunaga K, Sugiyama Y, Murakami S: Nonneuronal cholinergic system in human bladder urothelium. Urology 2006;67:425-430.
129 Hanna-Mitchell AT, Beckel JM, Barbadora S, Kanai AJ, de Groat WC, Birder LA: Nonneuronal acetylcholine and urinary bladder urothelium. Life Sci 2007;80:2298-2302.

130 Bschleipfer T, Schukowski K, Weidner W, Grando SA, Schwantes U, Kummer W, Lips KS: Expression and distribution of cholinergic receptors in the human urothelium. Life Sci 2007;80:2303-2307.

131 Zarghooni S, Wunsch J, Bodenbenner M, Bruggmann D, Grando SA, Schwantes U, Wess J, Kummer W, Lips KS: Expression of muscarinic and nicotinic acetylcholine receptors in the mouse urothelium. Life Sci 2007;80:2308-2313.

132 Chatterjee PK, Yeboah MM, Dowling O, Xue X, Powell SR, Al-Abed Y, Metz CN: Nicotinic acetylcholine receptor agonists attenuate septic acute kidney injury in mice by suppressing inflammation and proteasome activity. PloS One 2012;7:e35361.

133 Yeboah MM, Xue X, Duan B, Ochani M, Tracey KJ, Susin M, Metz CN: Cholinergic agonists attenuate renal ischemia-reperfusion injury in rats. Kidney Int 2008;74:62-69.

134 Sadis C, Teske G, Stokman G, Kubjak C, Claessen N, Moore F, Loi P, Diallo B, Barvais L, Goldman M, Florquin S, Le Moine A: Nicotine protects kidney from renal ischemia/ reperfusion injury through the cholinergic anti-inflammatory pathway. PloS One 2007; 2:e469.

135 Hua P, Feng W, Ji S, Raij L, Jaimes EA: Nicotine worsens the severity of nephropathy in diabetic mice: implications for the progression of kidney disease in smokers. Am J Physiol Renal Physiol 2010;299:F732-F739.

136 Mercado C, Jaimes EA: Cigarette smoking as a risk factor for atherosclerosis and renal disease: novel pathogenic insights. Curr Hypertens Rep 2007;9:66-72.

137 Abrams P, Cardozo L, Fall M, Griffiths D, Rosier P, Ulmsten U, van Kerrebroeck P, Victor A, Wein A, Standardisation Subcommittee of the International Continence Study: The standardisation of terminology of lower urinary tract function: report from the standardisation subcommittee of the international continence society. Neurourol Urodyn 2002;21:167-178.

138 Andersson KE, Yoshida M: Antimuscarinics and the overactive detrusor - which is the main mechanism of action? Eur Urol 2003; 43:1-5.

139 Yamaguchi O: Antimuscarinics and overactive bladder: other mechanism of action Neurourol Urodyn 2010;29:112-115.

140 Andersson KE: Antimuscarinic mechanisms and the overactive detrusor: an update. Eur Urol 2011;59:377-386.

141 Wein AJ: Re: antimuscarinic mechanisms and the overactive detrusor: an update. J Urol 2012;188:888-889.

142 Ochodnicky P, Uvelius B, Andersson KE, Michel MC: Autonomic nervous control of the urinary bladder. Acta Physiol (Oxf) 2013;207:16-33. 
143 Bschleipfer T, Weidner W, Kummer W, Lips KS: Does bladder outlet obstruction alter the non-neuronal cholinergic system of the human urothelium? Life Sci 2012;91:1082-1086.

-144 Bschleipfer T, Nandigama R, Moeller S, Illig C, Weidner W, Kummer W: Bladder outlet obstruction influences mRNA expression of cholinergic receptors on sensory neurons in mice. Life Sci 2012;91:1077-1081.

145 Weber S, Thiele H, Mir S, Toliat MR, Sozeri B, Reutter H, Draaken M, Ludwig M, Altmuller J, Frommolt P, Stuart HM, Ranjzad P, Hanley NA, Jennings R, Newman WG, Wilcox DT, Thiel U, Schlingmann KP, Beetz R, Hoyer PF, Konrad M, Schaefer F, Nurnberg P, Woolf AS: Muscarinic acetylcholine receptor M3 mutation causes urinary bladder disease and a prune-belly-like syndrome. Am J Hum Genet 2011;89:668-674.

- 146 Fritz S, Wessler I, Breitling R, Rossmanith W, Ojeda SR, Dissen GA, Amsterdam A, Mayerhofer A: Expression of muscarinic receptor types in the primate ovary and evidence for nonneuronal acetylcholine synthesis. J Clin Endocrinol Metab 2001;86:349-354.

- 147 Wessler I, Roth E, Deutsch C, Brockerhoff P, Bittinger F, Kirkpatrick CJ, Kilbinger H: Release of non-neuronal acetylcholine from the isolated human placenta is mediated by organic cation transporters. Br J Pharmacol 2001;134:951-956.

-148 Steffl M, Schweiger M, Wessler I, Kunz L, Mayerhofer A, Amselgruber WM: Nonneuronal acetylcholine and choline acetyltransferase in oviductal epithelial cells of cyclic and pregnant pigs. Anat Embryol 2006; 211:685-690.

149 Kitazawa T, Hirama R, Masunaga K, Nakamura T, Asakawa K, Cao J, Teraoka H, Unno T, Komori S, Yamada M, Wess J, Taneike T: Muscarinic receptor subtypes involved in carbachol-induced contraction of mouse uterine smooth muscle. Naunyn-Schmiedeberg's Arch Pharmacol 2008;377:503-513.

150 Sastry BV: Human placental cholinergic system. Biochem Pharmacol 1997;53:15771586.

- 151 Pavia J, Munoz M, Jimenez E, Martos F, Gonzalez-Correa JA, De la Cruz JP, Garcia V, Sanchez de la Cuesta F: Pharmacological characterization and distribution of muscarinic receptors in human placental syncytiotrophoblast brush-border and basal plasma membranes. Eur J Pharmacol 1997;320:209214.

-152 Wolff M, Noreikat K, Ibanez-Tallon I, Lips KS, Kölle S, Kummer W: Cholinergic receptors in the murine oviduct: inventory and coupling to intracellular calcium concentration. Life Sci 2012;91:1003-1008.

153 Shaw JLV, Oliver E, Lee K-F, Entrican G, Jabbour HN, Critchley HOD, Horne AW: Cotinine exposure increases fallopian tube PROKR1 expression via nicotinic AChRa-7: a potential mechanism explaining the link between smoking and tubal ectopic pregnancy. Am J Pathol 2010;177:2509-2515.
154 Sekhon HS, Jia Y, Raab R, Kuryatov A, Pankow JF, Whitsett JA, Lindstrom J, Spindel ER: Prenatal nicotine increases pulmonary alpha7 nicotinic receptor expression and alters fetal lung development in monkeys. J Clin Invest 1999;103:637-647.

155 Wongtrakool C, Grooms K, Ping XD, Rivera H, Ward J, Roser-Page S, Roman J, Brown LA, Gauthier TW: In utero nicotine exposure promotes M2 activation in neonatal mouse alveolar macrophages. Pediatr Res 2012;72:147-153.

156 Mimura K, Tomimatsu T, Sharentuya N, Tskitishvili E, Kinugasa-Taniguchi Y, Kanagawa T, Kimura T: Nicotine restores endothelial dysfunction caused by excess SFLT1 and SENG in an in vitro model of preeclamptic vascular endothelium: a possible therapeutic role of nicotinic acetylcholine receptor (nAChR) agonists for preeclampsia. Am J Obstet Gynecol 2010;202: 464 e461-e466.

157 Dowling O, Rochelson B, Way K, Al-Abed Y, Metz CN: Nicotine inhibits cytokine production by placenta cells via NFkappaB: potential role in pregnancy-induced hypertension. Mol Med 2007;13:576-583.

158 Schirmer SU, Eckhardt I, Lau H, Klein J, DeGraaf YC, Lips KS, Pineau C, Gibbins IL, Kummer W, Meinhardt A, Haberberger RV: The cholinergic system in rat testis is of nonneuronal origin. Reproduction (Cambridge) 2011;142:157-166.

159 Ibanez CF, Pelto-Huikko M, Soder O, Ritzen EM, Hersh LB, Hokfelt T, Persson H: Expression of choline acetyltransferase mRNA in spermatogenic cells results in an accumulation of the enzyme in the postacrosomal region of mature spermatozoa. Proc Natl Acad Sci USA 1991;88:3676-3680.

160 Ventura S, Pennefather J, Mitchelson F: Cholinergic innervation and function in the prostate gland. Pharmacol Ther 2002;94:93112.

161 White CW, Short JL, Haynes JM, Matsui M, Ventura S: Contractions of the mouse prostate elicited by acetylcholine are mediated by M(3) muscarinic receptors. J Pharmacol Exp Ther 2011;339:870-877.

162 Nieto-Cerón S, Vargas-López H, Pérez-Albacete M, Tovar-Zapata I, MartínezHernández P, Rodríguez-López JN, Cabezas-Herrera J: Analysis of cholinesterases in human prostate and sperm: implications in cancer and fertility. Chemicobiol Interact 2010;187:432-435.

163 Bray C, Son JH, Kumar P, Meizel S: Mice deficient in chRNA7, a subunit of the nicotinic acetylcholine receptor, produce sperm with impaired motility. Biol Reprod 2005; 73:807-814.

164 Dwivedi C, Long NJ: Effect of cholinergic agents on human spermatozoa motility. Biochem Med Metab Biol 1989;42:66-70.
65 Avellar MC, Siu ER, Yasuhara F, Marostica E, Porto CS: Muscarinic acetylcholine receptor subtypes in the male reproductive tract: expression and function in rat efferent ductules and epididymis. J Mol Neurosci 2010; 40:127-134.

166 Kawashima K, Fujii T: Extraneuronal cholinergic system in lymphocytes. Pharmacol Ther 2000;86:29-48.

167 Kawashima K, Kajiyama K, Fujimoto K, Oohata H, Suzuki T: Presence of acetylcholine in blood and its localization in circulating mononuclear leukocytes of humans. Biogenic Amines 1993;9:251-258.

168 Kawashima K, Fujii T, Moriwaki Y, Misawa $\mathrm{H}$ : Critical roles of acetylcholine and the muscarinic and nicotinic acetylcholine receptors in the regulation of immune function. Life Sci 2012;91:1027-1032.

169 Fujii T, Yamada S, Watanabe Y, Misawa H, Tajima S, Fujimoto K, Kasahara T, Kawashima K: Induction of choline acetyltransferase mRNA in human mononuclear leukocytes stimulated by phytohemagglutinin, a T-cell activator. J Neuroimmunol 1998;82:101-107.

170 Fujii T, Takada-Takatori Y, Horiguchi K, Kawashima K: Mediatophore regulates acetylcholine release from T cells. J Neuroimmunol 2012;244:16-22.

171 Sato KZ, Fujii T, Watanabe Y, Yamada S, Ando T, Kazuko F, Kawashima K: Diversity of mRNA expression for muscarinic acetylcholine receptor subtypes and neuronal nicotinic acetylcholine receptor subunits in human mononuclear leukocytes and leukemic cell lines. Neurosci Lett 1999;266:17-20.

172 Zimring JC, Kapp LM, Yamada M, Wess J, Kapp JA: Regulation of CD8+ cytolytic T lymphocyte differentiation by a cholinergic pathway. J Neuroimmunol 2005;164:66-75.

173 Fujii YX, Tashiro A, Arimoto K, Fujigaya H, Moriwaki Y, Misawa H, Fujii T, Matsui M, Kasahara T, Kawashima K: Diminished antigen-specific IgG1 and interleukin-6 production and acetylcholinesterase expression in combined M1 and M5 muscarinic acetylcholine receptor knockout mice. J Neuroimmunol 2007;188:80-85.

174 Sandberg G: Leukocyte mobilization from the guinea pig spleen by muscarinic cholinergic stimulation. Experientia 1994;50:40-43.

175 Wang H, Yu M, Ochani M, Amella CA, Tanovic M, Susarla S, Li JH, Wang H, Yang $\mathrm{H}$, Ulloa L, Al-Abed Y, Czura CJ, Tracey KJ: Nicotinic acetylcholine receptor alpha7 subunit is an essential regulator of inflammation. Nature 2003;421:384-388.

176 Borovikova LV, Ivanova S, Nardi D, Zhang M, Yang H, Ombrellino M, Tracey KJ: Role of vagus nerve signaling in CNI-1493-mediated suppression of acute inflammation. $\mathrm{Au}$ ton Neurosci Basic Clin 2000;85:141-147.

177 Tracey KJ: Reflex control of immunity. Nat Rev Immunol 2009;9:418-428.
Non-Neuronal Cholinergic System in Health and Disease
Pharmacology 2013;92:286-302 DOI: $10.1159 / 000355835$ 
-178 Xu ZP, Yang K, Xu GN, Zhu L, Hou LN, Zhang WH, Chen HZ, Cui YY: Role of M3 $\mathrm{mAChR}$ in in vivo and in vitro models of LPS-induced inflammatory response. Int Immunopharmacol 2012;14:320-327.

179 Kawashima K, Fujii T: The lymphocytic cholinergic system and its contribution to the regulation of immune activity. Life Sci 2003; 74:675-696.

180 Lee BH, Gauna AE, Perez G, Park YJ, Pauley KM, Kawai T, Cha S: Autoantibodies against muscarinic type 3 receptor in Sjögren's syndrome inhibit aquaporin 5 trafficking. PloS One 2013;8:e53113.

-181 Fujimoto K, Matsui M, Fujii T, Kawashima $\mathrm{K}$ : Decreased acetylcholine content and choline acetyltransferase mRNA expression in circulating mononuclear leukocytes and lymphoid organs of the spontaneously hypertensive rat. Life Sci 2001;69:1629-1638.

- 182 Valdes-Ferrer SI, Crispin JC, Belaunzaran PF, Cantu-Brito CG, Sierra-Madero J, Alcocer-Varela J: Acetylcholine-esterase inhibitor pyridostigmine decreases $\mathrm{T}$ cell overactivation in patients infected by HIV. AIDS Res Hum Retroviruses 2009;25:749-755.

183 Inkson CA, Brabbs AC, Grewal TS, Skerry TM, Genever PG: Characterization of acetylcholinesterase expression and secretion during osteoblast differentiation. Bone 2004;35:819-827.

184 En-Nosse M, Hartmann S, Trinkaus K, Alt V, Stigler B, Heiss C, Kilian O, Schnettler R, Lips KS: Expression of non-neuronal cholinergic system in osteoblast-like cells and its involvement in osteogenesis. Cell Tissue Res 2009;338:203-215.

185 Eimar H, Tamimi I, Murshed M, Tamimi F: Cholinergic regulation of bone. J Musculoskelet Neuronal Interact 2013;13:124132.

186 Bajayo A, Bar A, Denes A, Bachar M, Kram V, Attar-Namdar M, Zallone A, Kovacs KJ, Yirmiya R, Bab I: Skeletal parasympathetic innervation communicates central IL-1 signals regulating bone mass accrual. Proc Natl Acad Sci USA 2012;109:1545515460.

-187 Shi Y, Oury F, Yadav VK, Wess J, Liu XS, Guo XE, Murshed M, Karsenty G: Signaling through the M3 muscarinic receptor favors bone mass accrual by decreasing sympathetic activity. Cell Metab 2010;11: 231-238.

188 Kliemann K, Kneffel M, Bergen I, Kampschulte M, Langheinrich AC, Dürselen L, Ignatius A, Kilian O, Schnettler R, Lips KS: Quantitative analyses of bone composition in acetylcholine receptor M3R and alpha7 knockout mice. Life Sci 2012;91:9971002.

189 Hamann M, Chamoin MC, Portalier P, Bernheim L, Baroffio A, Widmer H, Bader CR, Ternaux JP: Synthesis and release of an acetylcholine-like compound by human myoblasts and myotubes. J Physiol 1995; 489:791-803.
90 Danielson P, Alfredson H, Forsgren S: Immunohistochemical and histochemical findings favoring the occurrence of autocrine/ paracrine as well as nerve-related cholinergic effects in chronic painful patellar tendon tendinosis. Microsc Res Tech 2006;69:808819.

191 Danielson P, Andersson G, Alfredson H, Forsgren S: Extensive expression of markers for acetylcholine synthesis and of M2 receptors in tenocytes in therapy-resistant chronic painful patellar tendon tendinosis - a pilot study. Life Sci 2007;80:2235-2238.

192 Bjur D, Danielson P, Alfredson H, Forsgren $\mathrm{S}$ : Presence of a non-neuronal cholinergic system and occurrence of up- and downregulation in expression of M2 muscarinic acetylcholine receptors: new aspects of importance regarding Achilles tendon tendinosis (tendinopathy). Cell Tissue Res 2008; 331:385-400.

193 Spang C, Alfredson H, Ferguson M, Roos B, Bagge J, Forsgren S: The plantaris tendon in association with mid-portion Achilles tendinosis - tendinosis-like morphological features and presence of a non-neuronal cholinergic system. Histol Histopathol 2013;28: 623-632.

194 Deng Y, Li T-Q, Yan Y-E, Magdalou J, Wang $\mathrm{H}$, Chen L-B: Effect of nicotine on chondrogenic differentiation of rat bone marrow mesenchymal stem cells in alginate bead culture. Bio-Medical Materials and Engineering 2012;22:81-87.

195 Ying X, Zhang W, Cheng S, Nie P, Cheng X, Shen Y, Wang W, Xue E, Chen Q, Kou D, Peng L, Zhang Y, Lu C: Nicotine-induced chondrogenic differentiation of human bone marrow stromal cells in vitro. Knee Surg Sports Traumatol Arthrosc 2012;20: 2329-2336.

196 Grimsholm O, Rantapaa-Dahlqvist S, Dalen $\mathrm{T}$, Forsgren S: Unexpected finding of a marked non-neuronal cholinergic system in human knee joint synovial tissue. Neurosci Lett 2008;442:128-133.

197 Forsgren S: Presence of ChAT mRNA and a very marked $\alpha 7 \mathrm{nAChR}$ immunoreaction in the synovial lining layer of the knee joint. Life Sci 2012;91:1043-1047.

198 Schubert J, Beckmann J, Hartmann S, Morhenn HG, Szalay G, Heiss C, Schnettler R, Lips KS: Expression of the non-neuronal cholinergic system in human knee synovial tissue from patients with rheumatoid arthritis and osteoarthritis. Life Sci 2012;91:10481052.

199 Kapoor SR, Filer A, Fitzpatrick MA, Fisher BA, Taylor PC, Buckley CD, McInnes IB, Raza K, Young SP: Metabolic profiling predicts response to anti-tumor necrosis factor alpha therapy in patients with rheumatoid arthritis. Arthritis Rheum 2013;65:14481456.
200 Waldburger JM, Boyle DL, Pavlov VA Tracey KJ, Firestein GS: Acetylcholine regulation of synoviocyte cytokine expression by the alpha7 nicotinic receptor. Arthritis Rheum 2008;58:3439-3449.

201 Van Maanen MA, Lebre MC, van der Poll T, LaRosa GJ, Elbaum D, Vervoordeldonk MJ Tak PP: Stimulation of nicotinic acetylcholine receptors attenuates collagen-induced arthritis in mice. Arthritis Rheum 2009;60: 114-122.

202 Lindblad SS, Mydel P, Jonsson IM, Senior RM, Tarkowski A, Bokarewa M: Smoking and nicotine exposure delay development of collagen-induced arthritis in mice. Arthritis Res Ther 2009;11:R88.

203 Yu H, Yang YH, Rajaiah R, Moudgil KD: Nicotine-induced differential modulation of autoimmune arthritis in the Lewis rat involves changes in interleukin-17 and anticyclic citrullinated peptide antibodies. Arthritis Rheum 2011;63:981-991.

204 Van Maanen MA, Stoof SP, Larosa GJ, Vervoordeldonk MJ, Tak PP: Role of the cholinergic nervous system in rheumatoid arthritis: aggravation of arthritis in nicotinic acetylcholine receptor alpha7 subunit gene knockout mice. Annals Rheum Dis 2010;69: 1717-1723.

205 Westman M, Saha S, Morshed M, Lampa J: Lack of acetylcholine nicotine alpha 7 receptor suppresses development of collagen-induced arthritis and adaptive immunity. Clin Exp Immunol 2010;162:62-67.

206 Buerkle H, Boschin M, Marcus MA, Brodner G, Wusten R, Van Aken H: Central and peripheral analgesia mediated by the acetylcholinesterase-inhibitor neostigmine in the rat inflamed knee joint model. Anesth Analg 1998;86:1027-1032.

207 Dogan N, Erdem AF, Erman Z, Kizilkaya M: The effects of bupivacaine and neostigmine on articular cartilage and synovium in the rabbit knee joint. J Int Med Res 2004;32: 513-519.

208 Rowley TJ, McKinstry A, Greenidge E, Smith W, Flood P: Antinociceptive and antiinflammatory effects of choline in a mouse model of postoperative pain. Br J Anaesthesia 2010;105:201-207.

-209 McIntosh JM, Absalom N, Chebib M, Elgoyhen $A B$, Vincler M: Alpha9 nicotinic acetylcholine receptors and the treatment of pain. Biochem Pharmacol 2009;78:693-702.

210 Baek YH, Choi DY, Yang HI, Park DS: Analgesic effect of electroacupuncture on inflammatory pain in the rat model of collagen-induced arthritis: mediation by cholinergic and serotonergic receptors. Brain Res 2005; 1057:181-185.

211 Motta PG, Perez AC, Alves DP, Duarte ID: Modulation of peripheral inflammatory pain thresholds by $\mathrm{M}(1)$ and nicotinic receptor antagonists. Pharmacology 2011;88: 309-315. 